University of Rhode Island

DigitalCommons@URI

Open Access Dissertations

2017

\title{
CES Involved Inhibition and Regulation
}

Yuanjun Shen

University of Rhode Island, yuanjun_shen@uri.edu

Follow this and additional works at: https://digitalcommons.uri.edu/oa_diss

\section{Recommended Citation}

Shen, Yuanjun, "CES Involved Inhibition and Regulation" (2017). Open Access Dissertations. Paper 656. https://digitalcommons.uri.edu/oa_diss/656

This Dissertation is brought to you for free and open access by DigitalCommons@URI. It has been accepted for inclusion in Open Access Dissertations by an authorized administrator of DigitalCommons@URI. For more information, please contact digitalcommons-group@uri.edu. 


\section{CES INVOLVED INHIBITION AND REGULATION}

BY

YUANJUN SHEN

A DISSERTATION SUBMITTED IN PARTIAL FULFILMENT

OF THE REQUIREMENTS FOR THE DEGREE OF

DOCTOR OF PHILOSOPHY

IN

PHARMACEUTICAL SCIENCES

UNIVERSITY OF RHODE ISLAND

2017 


\title{
DOCTOR OF PHILOSOPHY DISSERTATION
}

\author{
$\mathrm{OF}$ \\ YUANJUN SHEN
}

APPROVED:

DISSERTATION COMMITTEE:

MAJOR PROFESSOR

Bingfang Yan

Ruitang Deng

Joel M. Chandlee

Nasser H. Zawia

Dean of the Graduate School

UNIVERSITY OF RHODE ISLAND 


\begin{abstract}
Sofosbuvir has been widely adopted for Hepatitis C Virus (HCV) infection therapies through its effect as $\mathrm{HCV}$ non-structured protein 5B (NS5B) inhibitor, which is essential for HCV particle assembly. Sofosbuvir, as a prodrug, is activated through the hydrolysis by carboxylesterase 1 (CES1) and is reported to have limited interactions with cytochrome P450 enzymes (CYP450) and p-glycoprotein, which results in less clinical drug-drug interactions. However, reports showed fatal or nephrotoxic cases that utilized a co-therapy of Sofosbuvir with an anti-Human Immunodeficiency virus (HIV) agent, tenofovir disoproxil fumarate (TDF). This study was designed to give one explanation for these case reports. Interestingly, although Sofosbuvir is a CES1 substrate, it covalently inhibited CES2, but not CES1, at an IC50 of $0.8 \mathrm{uM}$, which was even more potent than reported inhibition on NS5B of HCV. Such inhibition was also proved to be caused by Sofosbuvir, but not its metabolites.
\end{abstract}

Tenofovir disoproxil fumarate (TDF) and tenofovir alafenamide fumarate (TAF) are prodrugs for tenofovir (TFV) in the therapies of Hepatitis B Virus (HBV) infections and Human Immunodeficiency Virus (HIV) infections. Both of them need to be monitored for severe hepatomegaly with steatosis. Although TDF was found to have mitochondria-depletion induced lipid metabolism dysfunction, it was not true for TAF. Therefore, we designed this study, trying to discover a possible explanation. Our research found that both TAF and TDF lead to lipid retention in Huh7 cells, with 
association of the induction of small heterodimer partner (SHP) expressions of both mRNA and protein. Further experiments proved that it was the prodrugs but not TFV that lead to the lipid retention and SHP induction. Moreover, TAF also showed a synergic lipid retention effect with ethanol (EtOH) co-treatment, possibly caused by the CES1-mediated ethyl transesterification pathway. 


\section{ACKNOWLEDGEMENT}

Foremost, I would like to express my deepest sense of gratitude to Dr. Bingfang Yan, a wonderful mentor and teacher, for his invaluable guidance, untiring help, assistance, and for providing me with the facilities and opportunity for advanced learning. May I build on his teachings and carry on his lessons to my future endeavors.

I am very thankful to Drs. Ruitang Deng, Joel Chandlee, Roberta King and Ying Zhang for their guidance, support, understanding and willingness to serve in my graduate committee. They have donated their time and efforts so that my future is secure and for that I am most appreciative.

I would also like to extend my thanks to the URI INBRE facility that offers excellent service for students and faculties in providing analytical instrumentation, which greatly helped me in most of the research.

Finally, my special thanks go to my friends and lab mates, Dr. Yi-tzai Roy Chen, Dr. Karen Ho, Marek Marczak, Zhen Xu, Eton Chen and Dongfang Yang for their friendship, constructive advice and boundless help during the course of my studies. 


\section{To my family}

To my father Rong Shen and my mother Linghua Ding whose love, struggle, encouragement, and everlasting support paved the way to my success.

To my grandparents Zhi'an Shen, Jing Wu, and Weixi Ding, who always stood by me every step of my way.

Finally to my grandmother Yuming $\mathrm{Hu}$, who will always guide me in my heart. 


\section{PREFACE}

This dissertation is a final work prepared as partial fulfillment for the degree of Doctor of Philosophy of Science in the College of Pharmacy.

Manuscript 1, titled "Covalent inhibition of carboxylesterase-2 by sofosbuvir and its effect on the hydrolytic activation of tenofovir disoproxil" was published in Journal of Hepatology in March 2017 (66:3 660-661), and is presented here as the manuscript format.

Manuscript 2, titled "The paradigm shift anti-hepatitis $\mathrm{C}$ viral agent, sofosbuvir, covalently inhibited carboxylesterase 2 with strong clinical implications", and Manuscript 3, titled "Tenofovil alafenamide and tenofovir disoproxil induced lipid accumulation in Huh7 cells through their regulations on small heterodimer partner with interactions of ethyl alcohol", are in preparation for publication after the dissertation is submitted to the Graduate School of University of Rhode Island, and they are presented here as the manuscript format.

All work supporting these three manuscripts was conducted at the University of Rhode Island, primarily in the College of Pharmacy from September 2013 to December 2017. 


\section{TABLE OF CONTENTS}

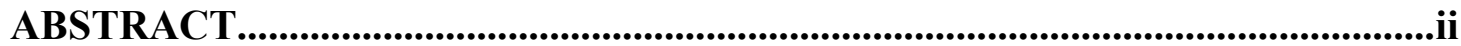

ACKNOWLEDGMENTS............................................................................................ iv

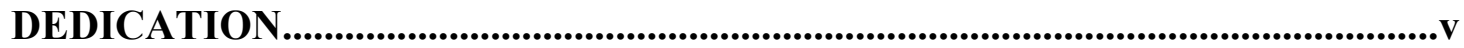

PREFACE ….........................................................................................................................vi

TABLE OF CONTENTS................................................................................ vii

LIST OF TABLES...................................................................................................viii

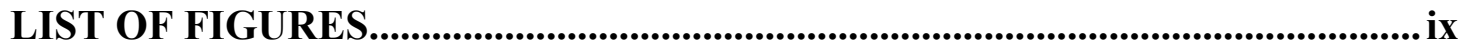

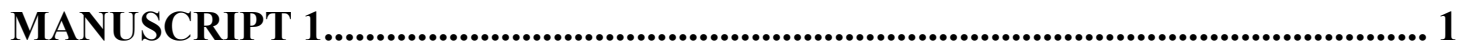

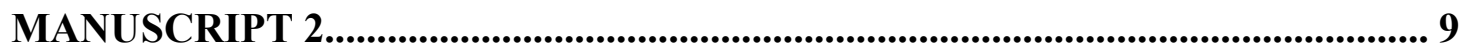

MANUSCRIPT 3 


\section{LIST OF TABLES}

TABLE

PAGE

Manuscript 3. Table 1. Guiding RNA of CRISPR plasmids..................................... 56 


\section{LIST OF FIGURES}

FIGURE

PAGE

Manuscript 1. Figure 1. Inhibition of CES2 by sofosbuvir......................................

Manuscript 2. Figure 1. Inhibition of carboxylesterase in mouse and rat microsomes...

Manuscript 2. Figure 2. Inhibition of SOF in recombinant proteins

Manuscript 2. Figure 3. Cytotoxicity change caused by SOF

Manuscript 2. Figure 4. SOF and metabolites inhibition on CES2

Manuscript 2. Figure 5. SOF docking profile on CES1 and CES2 36

Manuscript 3. Figure 1. Lipid retention in Huh7 cells by treating with TFV, TAF and

TDF 57

Manuscript 3. Figure 2. SHP regulation by treatment of TFV, TAF and TDF in Huh7

cells. 58

Manuscript 3. Figure 3. Lipid retention in Huh7 cells with SHP transfection 59

Manuscript 3. Figure 6. Lipid retention profiles in CRISPR screened Huh7 cells.....60

Manuscript 3. Figure 7. Lipid retention profile of TAF treatment in Huh7 cells co-treated with alcohol. 61 


\title{
Manuscript 1
}

Covalent inhibition of carboxylesterase-2 by sofosbuvir and its effect on the hydrolytic activation of tenofovir disoproxil

\author{
Yuanjun Shen, Bingfang Yan*
}

Biomedical and Pharmaceutical Sciences, University of Rhode Island, Kingston, RI, USA

Published in Journal of Hepatology, March 2017 
To the Editor:

Sofosbuvir is considered as a paradigm shift in treating hepatitis $\mathrm{C}$ viral infection (HCV) [1]. Patients co-infected with human immunodeficiency virus (HIV) usually receive both anti-HCV and antiretroviral therapy [2]. Emerging evidence, recently reported by this and other journals, has linked sofosbuvir-containing regimens to liver or kidney toxicity when co-administered with anti-HIV drugs [2-6]. Interestingly, sofosbuvir and some anti-HIV drugs such as tenofovir disoproxil contain ester and/or amide bonds. These chemical bonds are hydrolyzed by carboxylesterases. In humans, there are two major carboxylesterases: CES1 and CES2 [7].

This study reports that sofosbuvir is a potent and covalent CES2 inhibitor. Human liver or kidney microsomes were preincubated with sofosbuvir at $0-50 \mu \mathrm{M}$. The colorimetric substrate p-nitrophenylacetate (PNPA) was subsequently added. The hydrolysis of PNPA was monitored with a microplate-reader by an increase in the absorbance at $400 \mathrm{~nm}$ [8]. The liver microsomes were pooled from 20 donors including 12 males and 8 females. The kidney microsomes were pooled from 12 including 7 males and 5 females. As shown in Fig. 1A, sofosbuvir potently inhibited the hydrolysis by both liver and kidney microsomes. The inhibition of kidney hydrolysis was more profound. At $5 \mu \mathrm{M}$, sofosbuvir inhibited kidney hydrolysis by $82 \%$.

The kidney predominantly expresses CES2 but not CES1 [7], and the profound inhibition of the kidney hydrolysis suggested that CES2 was a sensitive target of 
sofosbuvir. It has been reported that sofosbuvir was a CES1 substrate [9]. These observations pointed to the possibility that sofosbuvir inhibited CES2 through a mechanism other than competitive inhibition. We next tested whether covalent modification was involved in the inhibition. Liver and kidney microsomes were incubated with sofosbuvir at $0-10 \mu \mathrm{M}$. The reaction mixtures were subjected to electrophoresis (native gel) to remove unbound sofosbuvir. The gel was then stained for carboxylesterase activity [8]. As expected, this method detected two activity bands in liver microsomes (Fig. 1B). The activity band with the slower mobility corresponded to CES1 and was not affected by sofosbuvir except at $10 \mu \mathrm{M}(15 \%$ inhibition). In contrast, the activity band with the faster mobility (i.e., CES2) was drastically reduced by $1 \mu \mathrm{M}$ sofosbuvir and completely eliminated by $10 \mu \mathrm{M}$ (Fig. 1B). Similar observations were made on CES2 in kidney microsomes (i.e., CES2).

To shed light on the significance of the inhibition in relation to interactions with anti-HIV drugs, lysates from CES2-transfected cells were pre-incubated with sofosbuvir or solvent and tested for the hydrolysis of tenofovir disoproxil fumarate (fumaric acid salt), a widely used anti-HIV agent that has been implicated in organ toxicity with sofosbuvir [2-6]. The reactions were precipitated with acetonitrile and analyzed by high performance liquid chromatography. As shown in Fig. 1C (top), incubation with CES2 caused $70 \%$ conversion of tenofovir disoproxil into its hydrolytic metabolite: tenofovir. However, the hydrolytic conversion was inhibited by sofosbuvir. The incubations were performed at pharmacological concentrations in the liver for both tenofovir disoproxil fumarate and sofosbuvir [5]. 
Sofosbuvir is a substrate of drug transporters [10]. Therefore, it has been assumed that sofosbuvir interacts with drugs that share these transporters. In this study, we have demonstrated that sofosbuvir is also a potent and covalent CES2 inhibitor, providing a novel mechanism for interactions with drugs that are CES2 substrates such as tenofovir. Indeed, it has been reported that sofosbuvir-containing regimens increased the blood exposure of tenofovir by as much as $98 \%$ [10]. The toxicological consequences of the hydrolytic interactions, on the other hand, depend on the relative toxicity between a parent drug and its hydrolytic metabolite. As for tenofovir disoproxil, the inhibition of its hydrolysis may decrease the toxicity if its hydrolytic metabolite is more toxic than the parent drug. In this case, organ-based hydrolysis may come into play. For example, sofosbuvir at a certain dose inhibits liver and kidney CES2 with the liver enzyme being inhibited to a greater extent. The blood concentration of tenofovir disoproxil will elevate, the kidney hydrolysis will increase, and kidney toxicity might be more evident. Alternatively, predominant inhibition of intestinal CES2 by sofosbuvir may facilitate the absorption of tenofovir disoproxil, leading to elevated levels of this anti-HIV drug in the liver with increased risk of hepatic toxicity upon hydrolysis.

Another major variable is the overall activity of drug transporters for a parent drug and its metabolite. Hydrolysis of an ester, for example, produces a carboxylic acid species [7]. This molecular species is negatively charged at physiological conditions and effluxed out by transporters. As a result, cells with high level expression of 
relevant transporters may not exhibit severe toxicity. Therefore, the toxicological consequences of the hydrolytic interactions depend on the interplay between CES2 and drug transporters, and the interplay may vary depending on an organ. In addition, sofosbuvir is commonly used together with other anti-HCV drugs, particularly with the NS5A inhibitor ledipasvir [5]. It remains to be determined whether ledipasvir contributed to the observed toxicity [2-5]. Nevertheless, clinical trials are required to fully assess the pharmacological and toxicological significance of the potent and covalent inhibition of CES2 by sofosbuvir. The authors have been actively pursuing this possibility.

Financial support

This work was supported by NIH grants R01GM61988, R01EB018748 and R15AT007705.

Conflict of interest

The authors who have taken part in this study declared that they do not have anything to disclose regarding funding or conflict of interest with respect to this manuscript.

\section{References}

[1] deLemos AS, Chung RT. Hepatitis C treatment: an incipient therapeutic revolution. Trends Mol Med 2014;20:315-321.

[2] Poizot-Martin I, Naqvi A, Obry-Roguet V, Valantin MA, Cuzin L, Billaud E, et alHepadat'AIDS Study Group. Potential for drug-drug interactions between antiretrovirals and $\mathrm{HCV}$ direct acting antivirals in a large cohort of HIV/HCV coinfected patients. PLoS One 2015;10 e 0141164. 
[3] Marchan-Lopez A, Dominguez-Dominguez L, Kessler-Saiz P, Jarrin-Estupiñan ME. Liver failure in human immunodeficiency virus - Hepatitis $\mathrm{C}$ virus coinfection treated with sofosbuvir, ledipasvir and antiretroviral therapy. J Hepatol 2016;64:752-753.

[4] Wanchoo R, Thakkar J, Schwartz D, Jhaveri KD. Harvoni (ledipasvir with sofosbuvir)-induced renal injury. Am J Gastroenterol 2016;111:148-149.

[5] Bunnell KL, Vibhakar S, Glowacki RC, Gallagher MA, Osei AM, Huhn G. Nephrotoxicity associated with concomitant use of ledipasvir-sofosbuvir and tenofovir in a patient with hepatitis $\mathrm{C}$ virus and human immunodeficiency virus coinfection. Pharmacotherapy 2016;36:e148-e153.

[6] Tseng A, Wong DK. Hepatotoxicity and potential drug interaction with ledipasvir/sofosbuvir in HIV/HCV infected patients. J Hepatol 2016;65:651-653.

[7] Dyson JK, Hutchinson J, Harrison L, Rotimi O, Tiniakos D, Foster GR, et al. Liver toxicity associated with sofosbuvir, an NS5A inhibitor and ribavirin use. J Hepatol 2016;64:234-238.

[8] Xiao D, Shi D, Yang D, Barthel B, Koch TH, Yan B. Carboxylesterase-2 is a highly sensitive target of the antiobesity agent orlistat with profound implications in the activation of anticancer prodrugs. Biochem Pharmacol 2013;85:439-447.

[9] Murakami E, Tolstykh T, Bao H, Niu C, Steuer HM, Bao D, et al. Mechanism of activation of PSI-7851 and its diastereoisomer PSI-7977. J Biol Chem 2010;285:34337-34347.

[10] DATA SHEET HARVONI at www.medsafe.govt.nz/profs/datasheet/h/HarvoniTab.PDF. 
Corresponding author. Address: Department of Biomedical and Pharmaceutical Sciences, Center for Integrated Drug Development, University of Rhode Island, Kingston, RI 02881, USA.

Tel.: +1 (401) 874 5032; fax: +1 (401) 8745048.

E-mail address: byan@uri.edu 

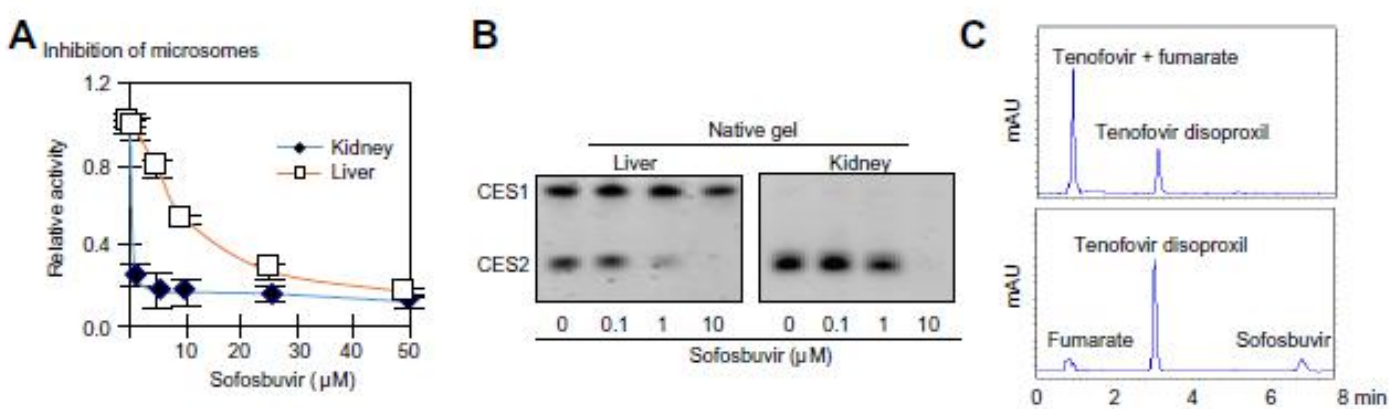

Figure 1. Inhibition of CES2 by sofosbuvir. (A) Inhibition of microsomal hydrolysis by sofosbuvir microsomes for human liver $(0.25 \mu \mathrm{g} /$ per well) or kidney $(1 \mu \mathrm{g} / \mathrm{per}$ well $)$ were incubated with sofosbuvir for $120 \mathrm{~min}$ at $0-50 \mu \mathrm{M}$ in a total volume of $90 \mu \mathrm{L}$ and then $10 \mu \mathrm{L}$ of p-nitrophenylacetate (PNPA) was added at a final concentration of $1 \mathrm{mM}$. The hydrolysis of PNPA was monitored with a microplate-reader from an increase in the absorbance at $400 \mathrm{~nm}$. (B) Native-gel electrophoresis stained for hydrolytic activity microsomes $(0.25 \mu \mathrm{g})$ were incubated with sofosbuvir at $0-10 \mu \mathrm{M}$ and subjected to native gel electrophoresis and stained for esterase activity with 4-methylumbelliferylacetate. (C) Inhibited hydrolysis of tenofovir disoproxil fumarate lysates from CES2 transfected cells were pre-incubated with sofosbuvir at $20 \mu \mathrm{M}$ or the reaction buffer at $37^{\circ} \mathrm{C}$ for $120 \mathrm{~min}$, followed by addition of tenofovir disoproxil fumarate at a final concentration of $20 \mu \mathrm{M}$. The incubations lasted for an additional $30 \mathrm{~min}$ and were then mixed with acetonitrile at a final concentration of $66 \%$. The reactions were centrifuged to remove the proteins and the supernatants were analyzed by high performance liquid chromatography (Hitachi-300). 


\title{
Manuscript 2
}

The paradigm shift anti-hepatitis $C$ viral agent, sofosbuvir, covalently inhibited carboxylesterase 2 with strong clinical implications

\author{
Yuanjun Shen, Bingfang Yan*
}

Biomedical and Pharmaceutical Sciences, University of Rhode Island, Kingston, RI, USA 


\begin{abstract}
Sofosbuvir has been widely adopted for Hepatitis C Virus (HCV) infection therapies through its effect as a $\mathrm{HCV}$ non-structured protein 5B (NS5B) inhibitor, which is essential for $\mathrm{HCV}$ reproduction. Sofosbuvir, as a prodrug, is activated through the hydrolysis by carboxylesterase 1 (CES1) and was reported to have limited interactions with cytochrome P450 enzymes (CYP450) and p-glycoprotein, which resulted in less clinical drug-drug interactions. However, reports showed fatal or nephrotoxic cases that utilized a co-therapy of Sofosbuvir with an anti-Human Immunodeficiency virus (HIV) agent, tenofovir disoproxil fumarate (TDF). This study was designed to provide one possible explanation for these case reports. Interestingly, although Sofosbuvir is a CES1 substrate, it covalently inhibited CES2, but not CES1, at an IC50 of 0.8uM, which was even more potent than reported inhibition on NS5B of HCV. Such inhibition was also prove to be caused by Sofosbuvir, but not its metabolites.
\end{abstract}

\title{
Introduction
}

The updated report from World Health Organization (WHO) in 2017 showed that 130-150 million people worldwide has been infected by Hepatitis C virus (HCV), and approximately 500,000 patients die because of HCV-related liver diseases each year (WHO, 2017). Mohd Hanafiah K et al. (2013) summarized that the prevalence of $\mathrm{HCV}$ infection was moderate to high in old continents, especially in China, Central and West Asia and North Africa. After the infection of hepatocytes, the HCV positive-sense single-stranded RNA (+ssRA) starts to serve as a messenger RNA 
(mRNA) for translation, leading to the production of a large polyprotein, which can be cleaved into 4 structural proteins, forming the virus particles, and 6 non-structural (NS) proteins, essential for ssRNA translation and particle assembly (Lindenbach BD and Rice CM, 2005). Since the 1980s, ribavirin in combination with PEGylated interferon-alpha (PEG-IFN- $\alpha$ ) has been used as the standard treatment, even though with low efficacy in some HCV genotypes and potential severe side effects (Barakat KH et al., 2013). However, with the advances in research, most newly developed anti-HCV drugs, or so-called direct-acting antivirals (DAAs), target on four of the NS proteins: NS3/4A, the serine protease; NS5A, the large phosphoprotein; and NS5B, the RNA-dependent RNA polymerase (RdRp).

Since 2005, researchers has tried to design a NS5B inhibitor according to the crystal structure of its active pocket. However, when PSI-6206 was synthesized (Clark JL et al., 2005), it was unable to inhibit NS5B because of the difficulty to be converted into its active triphosphate form in vivo, PSI-7409 (Clark JL et al., 2006). Therefore, a new compound PSI-7851, the prodrug of PSI-7409, was synthesized, which has been shown to be very potent to clear HCV in vitro (Lam AM et al., 2010). Further studies showed that one of the diasteroisomers, PSI-7977, now named as sofosbuvir (SOF), was even more potent than the mixture (Murakami E et al., 2010). Upon entering the human hepatocytes, SOF is hydrolyzed by human carboxylesterase 1 (CES1) into a carboxylate intermediate, which can be quickly metabolized into the monophosphate nucleotide analog by histidine triad nucleotide-binding protein 1 (Hint 1). With further catalysis by UMP-CMP kinase and nucleoside diphosphate kinase, it finally is 
converted into PSI-7409, the active triphosphate analog. SOF was considered to be tolerant to any degree of $\mathrm{HCV}$ patients, because it was not metabolized by CYP enzymes, neither did it regulate CYP expressions (Kumari R and Nguyen MH, 2015). However, the use of SOF together with other DAA's, with the standard of care (SOC) treatment or with anti-human immunodeficient virus (HIV) drugs, there were quite a few cases with hepatic and renal toxicity.

In early 2015, a group of researchers from the United Kingdom reported two cases of severe liver toxicity associated with the use of SOF. In one of the cases, the male patient was pretreated with anti-HIV drugs, including tenofovir disproxil fumarate (TDF) before he was co-treated with anti-HCV drugs (SOF, Ledipasvir and Ribavirin). After 18 days, the bilirubin level was dramatically higher than that before the anti-HCV co-treatment. Although the therapy successfully controlled the HCV RNA level, his liver function was severely compromised, and was continuously deteriorated even after the interruption of anti-HCV therapy, leading to his death on day 38 (Dyson JK et al., 2016). A similar case was reported from Spain indicating that it was because of SOF and/or Ledipasvir, but not related to the use of Ribavirin, that caused the increase of bilirubin (Marchan-Lopez A et al., 2015). Moreover, reports also indicated SOF-induced kidney toxicity. In 2016, a case of acute kidney injury was reported as a 56-year-old female patient with HIV infection took Ledipasvir and SOF together with TDF-based anti-HIV treatment, and was diagnosed with acute tubular necrosis and acute interstitial nephritis 8 weeks after the anti-HCV treatment, presented by the dramatically increased levels of blood urea nitrogen and serum 
creatinine (Bunnell KL et al., 2016). These reports suggested a need to have a more cautious view on the metabolisms and potential drug-drug interactions (DDI) that involved SOF.

In this study, we have demonstrated that SOF was an irreversible human CES2 inhibitor, which potentially explains the hepatic and renal toxicity caused by the use of SOF in multiple drug therapies.

\section{Materials and methods}

\section{Chemicals and supplies}

Sofosbuvir (PSI-7977) and Tenofovir disoproxil fumurate were obtained from MedChemExpress (Monmouth Junction, NJ). PSI-7411 ammonium salt, and PSI-352707 ammonium salt were obtained from Toronto Research Chemicals Inc (Toronto, Ontario, Canada). Thiazolyl blue tetrazolium bromide (MTT) and 4-methylumbelliferyl acetate (MUA) were obtained from Sigma (St. Louis, MO). 4-nitrophenol acetate was obtained from Santa Cruz Biotechnology (Dallas, TX). Dulbecco's modified eagle medium (DMEM) was obtained from Life Technologies (Carlsbad, CA). The goat anti-rabbit IgG conjugated with horseradish peroxidase was obtained from Pierce (Rockford, IL). Nitrocellulose membranes were obtained from Bio-Rad (Hercules, CA). Expression constructs for mouse CESs were purchased from OriGene (Rockville, MD). Mouse and rat microsomes were obtained from XenoTech 
(Kansas City, KS). Unless otherwise specified, all other reagents were obtained from Fisher Scientific (Fair Lawn, NJ).

\section{Cell culture and treatment}

HEK 293FT cells were stably transfected with human CES1 and CES2 plasmid constructs previously in our lab, and were maintained in full growth medium (DMEM, $10 \%$ FBS, $1 \mathrm{X}$ nonessential amino acid, and $1 \mathrm{X}$ penicillin/streptomycin) with puromycin or G418 respectively. Human recombinant CES1 and CES2 proteins were harvest from these two cell lines. Particularly, CES2 stable cells were seeded into 96-well plates (5,000/well), and were treated with SOF alone, CPT-11 alone or both in normal medium for $48 \mathrm{~h}$, and images of the cell morphology were taken by using the Evos Imaging System. Thereafter, the medium was replaced with fresh medium containing MTT [(4,5-dimethylthiazolyl-2)- ,5- diphenyltetrazolium bromide] at a final concentration of $0.5 \mathrm{mg} / \mathrm{ml}$. After a $2 \mathrm{~h}$ incubation at $37^{\circ} \mathrm{C}$, the medium was gently decanted, and DMSO (100 $\mu \mathrm{L} /$ well) was added to dissolve formazan product. The optical density (OD) was determined at $570 \mathrm{~nm}$, and the final OD values were calculated by subtracting the background reading (no seeded cells).

\section{Recombinant protein and enzyme activity assay}

Mouse recombinant carboxylesterase proteins were collected from $293 \mathrm{~T}$ cells transiently transfected with the plasmids, while human recombinant carboxylesterase proteins were collected from stably tranfected cells. The cells were rinsed by PBS and lysed in $100 \mathrm{mM}$ tris buffer $(\mathrm{pH}$ 7.4) by a sonifier, and the cells debris was removed 
by centrifugation at $12,000 \mathrm{~g}, 4^{\circ} \mathrm{C}$ for $10 \mathrm{~min}$. The supernatants were diluted in $100 \mathrm{mM}$ potassium phosphate buffer ( $\mathrm{pH} 7.4$ ) and incubated with SOF in 96-well plates for $2 \mathrm{hr}$ at $37^{\circ} \mathrm{C}$. Fresh $2 \mathrm{mM}$ nitrophenyl acetate in the potassium phophate buffer from its acetonitrile stock solution was prepared, and $50 \mathrm{uL}$ of the working substrate solution was added to each well of the 96-well plate. The kinetics of nitrophenyl acetate hydrolysis was measured at $400 \mathrm{~nm}$ for $15 \mathrm{~min}$ after its addition by using SpectraMax M2 Plate Reader.

\section{Western blot}

Cell lysates $(2-20 \mu \mathrm{g})$ were resolved by $7.5 \%$ SDS - polyacrylamide gel electrophoresis in a mini-gel apparatus (BioRad Laboratories, Hercules, CA) and transferred electrophoretically to nitrocellulose membranes; while samples separated by native gel electrophoresis were transfered to nitrocellulose membranes. After nonspecific binding sites were blocked with 5\% nonfat milk, the blots were incubated with an antibody against human carboxylesterases. The primary antibodies were subsequently localized with a secondary antibody conjugated with horseradish

peroxidase. Horseradish peroxidase activity was detected with a chemiluminescent kit (SuperSignal West Pico; Pierce Chemical). The chemiluminescent signal was captured by MyECL Imager.

\section{Molecular modeling}

To gain molecular insight regarding sofosbuvir-inhibition of CES's as well substrates docking, we performed molecular modeling and docking studies. The structure of 
CES2 was modeled with Discovery Studio based on the crystal structure of CES1 (3K9B; Hemmert AC et al., 2010), whose structure was retrieved from the Protein Data Bank (www.pdb.org). Only side chain A was used, water molecules were removed, and hydrogen atoms were added if they were missing in the original structural file by the application of UCSF chimera (Pettersen EF et al., 2004). Standard protonation states of the residues were adopted to produce the charged acidic and basic side chains as well as the $\mathrm{N}$ - and $\mathrm{C}$-termini. The homology modeling of CES2 was also performed with Discovery Studio-client (Dassault Systèmes BIOVIA, 2016) based on sequence similarity and the homology/analogy recognition engine Phyre. The 3-D model of CES2 was evaluated with the "Verify Protein (Profiles-3D)". The CES2 homology model was then finalized by using rabbit liver carboxylesterase structure (1K4Y; Bencharit S et al., 2002). The modeled CES2 structure was tested for the interaction with sofosbuvir with Autodock 4.2.6 (Morris GM et al., 2009). To compare CES1 with CES2 for the residues interacting with sofosbuvir, two major sequences of CES2 were replaced with the corresponding sequences of CES1. The subsequent protein mutant was analyzed for the changes in the interaction with sofosbuvir. Once again, the 3-D structure was constructed with Discovery Studio but the interaction was determined with Autodock 4.2.6. All the final figures of were visualized through Discovery Studio.

\section{Statistics}

Data are presented as mean $\pm \mathrm{SD}$ of at least three separate experiments. Statistical significance between two means was made by one-way ANOVA followed by a 
Tukey's comparison test $(\mathrm{p}<0.05)$. Statistical analysis was performed using online SAS OnDemand.

\section{Results}

SOF inhibited mouse ces activities in vitro. It was reported in our previous papers that, in consideration of carboxylesterases inhibition by orlistat, mouse is a better model compared with rat (Xiao D et al., 2013). In order to determine if this is also the same case in this study, microsomes from mouse and rat were utilized to test the inhibition profiles caused by SOF. First of all, mouse liver, kidney and intestine microsomes were incubated with SOF and tested for their remaining hydrolytic activity (Figure 1A). The SOF-induced hydrolytic inhibition was observed the most strongly in intestine microsomes, which exhibited about an $80 \%$ decrease when incubated with SOF at $5 \mu \mathrm{M}$; interestingly, however, although kidney microsome exhibited a quicker hydrolytic activity decrease compared with the liver counterpart, they achieved a similar end point activity (both about 60\% decrease). Further verification was based on native gel electrophoresis, which is a technique that can preserve the activities of the proteins during separation. As suggested from the gel, there was no SOF-induced inhibition on mouse ces1 family enzymes, ces1d and ces1e; while mouse ces 2 family enzymes, ces $2 \mathrm{c}$ and ces $2 \mathrm{e}$, showed significant activity decrease (Figure 1C). However, the enzyme inhibition in rats samples (Figure 1B, 1D) was not as much compared with mouse. One specific point was that rat samples exhibited more abundant Ces 1 family proteins than possible Ces2 proteins, which 
might also contribute to the lower degree of inhibition compared with mouse samples. Moreover, although rat intestine micrsome expressed a possible Ces 2 family protein, its inhibition was not as profound as its counterpart in mouse. The in vitro study not only confirmed that mouse was a better model for CES inhibition, but also indicated that it was ces2 family but not ces1 family that can be inhibited by SOF.

SOF inhibited ces 2 family. The in vitro data already indicated that SOF only inhibited ces 2 family but not 1 family in microsomes. We further tested the inhibition of enzymatic activity in recombinant mouse, rat and human CES proteins. Figure 2A showed that mouse ces2e was significantly inhibited by SOF at the concentration of $0.1 \mu \mathrm{M}$, and when the concentration reached to $1 \mu \mathrm{M}$, both ces $2 \mathrm{c}$ and ces $2 \mathrm{e}$ showed significant hydrolytic inhibition; interestingly, although ces1d kept exhibiting similar enzyme activity compared with cesle at the SOF concentrations of 0.1 and $1 \mu \mathrm{M}$, when SOF concentration reached to $10 \mu \mathrm{M}$, the inhibition was also significantly stronger than cesle. This observation was possibly due to the competitive inhibition of SOF as the substrate of ces 1 family enzymes. Moreover, although not shown in microsome analysis, SOF exhibited dose-dependent enzyme inhibition in both rat Ces1d and Ces1e, which resembled the results of mouse ces1d and ces1e, suggesting such inhibition was also resulted from competitive inhibition (Figure 2B). Similarly, human CES1 also showed significant but slow hydrolytic decrease after incubated with SOF; however, the inhibition was much more significant in CES2, which showed a $50 \%$ decrease when SOF concentration was $0.1 \mu \mathrm{M}$ and an over $99 \%$ decrease when SOF concentration was more than $1 \mu \mathrm{M}$ (Figure 2C). These results 
also indicated that mouse ces1e and ces2e share similar activities with human CES1 and CES2, respectively.

Human CES2 inhibition by SOF changed cell hydrolysis ability. We next tested whether such an inhibition on human CES2 took place in cells. The cell line chosen for the cell survival rate assay was $293 \mathrm{~T}$ cells transiently transfected with CES2 plasmid. Irinotecan (CPT-11) was used as the CES2 activity indicator in cells because it can only show its cytotoxicity after its hydrolysis by CES2 into SN-38 (Humerickhouse $\mathrm{R}$ et al., 2000). Figure $3 \mathrm{~A}$ showed that CPT-11 caused about $40 \%$ decrease of cell survival rate $(\mathrm{p}<0.05)$, while the co-treatment of SOF with CPT-11 significantly decreased the cytotoxicity, with a cell survival rate at about $65 \%$, which indicated a strong in cell CES2 inhibition with SOF treatment. The cell morphology images further confirmed the above observation in the MTT assay. Cells treated with CPT-11 alone not only exhibited a decreased cell density, but also an altered cell morphology; however, this morphology change was reversed by SOF co-treatment (Figure 3B).

The human CES2 inhibition by SOF was irreversible, and the major metabolites did not have inhibition activity. We further studied the inhibition by SOF when CES2 was mixed with CES1. Figure 4A confirmed that CES2 was much more sensitive to the inhibition compared with CES1; therefore, the activity decrease of the mixture was primarily caused by the inhibition on CES2. This result was further confirmed by native gel electrophoresis (Figure 4B). As is already known, SOF is the 
substrate of CES1. The hydrolysis of SOF leads to compound PSI-352707 (M1), and M1 can be quickly metabolized into PSI-7411 (M2) in cells (Murakami E et al., 2010, Figure 4E). Figure 4c showed that when SOF, M1 and M2 incubated with CES2, only SOF was able to inhibit the enzyme activity; moreover, if SOF was incubated with CES1 for $0.5 \mathrm{hr}$ or $2 \mathrm{hr}$, and then incubated with CES2, the inhibition activity was decreased (Figure 4D). Native gel electrophoresis is able to separate drugs from enzymes if they are not bound covalently. Briefly, free or weakly bound small molecule drugs in the electric field will be charged and quickly removed from the gel; however, drugs that covalently bind to enzymes will stay with the protein and keep the inhibition effect with it. In Figure 4B and 4D, the mixture of CES1 and CES2 incubated with SOF only affected the enzyme activity of CES2 but not CES1, indicating the inhibition was caused by the covalent interaction between SOF and CES2, regardless of the existence of CES1; in another word, SOF that escaped from CES1 hydrolysis will covalently bind to CES2 without any further effect caused by CES1.

CES2 may be inhibited by SOF allosterically. National Center for Biotechnology Information (NCBI) offered the FASTA protein sequence of CES1 and CES2, with which the Basic Local Alignment Search Tool (BLAST) on NCBI website generated the alignment result showing that there were $97 \%$ alignment (defined as query cover), although the sequence shared only $47 \%$ identity. SOF is the substrate of CES1; therefore, it is not unusual to predict that SOF inhibits CES2 in its active pocket. However, an enzyme kinetic study showed that the inhibition of SOF on CES2 was 
achieved in a non-competitive pattern, with an average $\mathrm{Km}$ value of $394.7 \pm 15.4 \mu \mathrm{M}$ measured by the rate of hydrolysis of nitrophenyl acetate (data not shown). Currently, there is no ready-to-use CES2 computer three-dimensional model from Protein Data Bank (PDB); therefore, we used human CES1 as the template to build the homology model of CES2 through Discovery Studio ${ }^{\circledR}$. This homology model was also refined by Rabbit CES2. A docking attempt of CES2 homology structure with SOF in Discovery Studio showed that after the entering the active pocket, SOF exhibited more non-polar interaction in CES2 than in CES1, indicating a possible explanation for different inhibition profiles. Moreover, the missing region 303-318 in CES2 might be responsible for the inhibition of CES2 by SOF, which might be able to stabilize this region in CES1 (Figure 5A and 5B). Further analysis at the sequence alignment indicated that region 303-318 may be important for substrate-inhibitor specificity in this case.

\section{Discussion}

SOF was reported to be metabolized mainly in the liver (Murakami E et al., 2010) and the final inactive metabolite, GS331007, was primarily excreted by the kidneys (Kirby BJ et al., 2015). Liver enzymes human CES1 and cathepsin A (CatA) are the two enzymes for SOF hydrolysis; however, with a much higher abundance than CatA in liver, CES1 is considered as the major one. CES1 mutants are common in humans, which leads to the changes of drug metabolisms, such as oseltamivir (Zhu HJ et al., 
2009), clopidogrel (Tang M et al., 2006) and lidocaine (Ercolani G et al., 2000). Our study has revealed that although SOF is the substrate of CES1, as long as its prodrug form appeared in the system, CES2 can be inhibited regardless of the existence of CES1. Therefore, certain mutants in CES1, such as G143E (Shi Jian et al., 2016), may be unable to hydrolyze SOF efficiently enough to stop further CES2 inhibition, which may also explain the SOF-induced hepatotoxicity. On the other hand, the evaluation of kidney functions are clinically determined by serum creatinine level. Generally speaking, an increase of more than $0.3 \mathrm{mg} / \mathrm{dL}$ serum creatinine is considered as the marker of acute kidney injury (AKI). Several clinical studies have revealed the association between AKI and SOF related HCV therapy. Maan JFE et al. (2016) reported that $11.2 \%$ of the patients receiving SOF experienced AKI, and among whom only $69.2 \%$ achieved sustained virological response (SVR); however, in patients that did not experience AKI in SOF treatment, $84.5 \%$ of them achieved SVR, suggesting that SOF-induced AKI was also related to the decrease of anti-HCV efficacy, possibly due to mutations of CES1. These results suggested a complicated interplay between CES1 and CES2 in the metabolism of SOF.

Importantly, it has drawn greater concerns about the patients with HIV and HCV coinfections, particularly because both of the viruses are bloodborne and share very similar transmit pathways, such as sexual contact and injection drug uses. Additionally, studies found that, compared with HIV-negative individuals, HIV-infected patients were six times more prevalent to $\mathrm{HCV}$ infection, especially in drug use groups (Platt L et al., 2016). TDF is one of the most commonly used drug 
anti-HIV therapies for co-infected patients. It is not uncommon to see renal toxicity induced by TDF treatment, which was caused by tenofovir-induced mitochondrial tubulopathy after the hydrolysis of TDF in situ (Moyle G, 2005; Lebrech D., et al., 2009 ). TDF, as a prodrug, is hydrolyzed by esterases into tenofovir to exhibit its anti-HIV activity. Clinical studies for SOF has shown a dramatic increase of TDF plasma concentration to $1.98(1.77-2.03)$ times during co-treatment compared to that without SOF (New Zealand Medsafe, Havoni Data Sheet, 2017). Clinical reports also associated nephrotoxicity with the combined therapy of TDF and SOF (Bunnell KL et al., 2016). In our former study (Shen and Yan, 2016), it has been observed that TDF was the substrate for both human CES1 and CES2, but its hydrolysis was much more quickly catalyzed by CES2. Through our study, SOF irreversibly inhibited CES2 in gut and liver, which could explain the elevated TDF exposure and the indicated nephrotoxicity when TDF co-treated with SOF.

A more important issue may reside in internal circadian changes of CES. CES is regulated by several nuclear receptors, including pregnane $\mathrm{X}$ receptor (PXR) and differentiated embryo chondrocyte (DEC). For example, it was reported that the treatment of fluoxetine in HepG2 cells lead to an decrease of PXR and an increase of DEC1, which was related to the reduction of CES1 and CES2 expression (Shang W et al., 2016). PXR has been long reported to regulate cytochrome P450 (CYP450) enzymes (Bertilsson G. et al., 1998); meanwhile, its regulation of CES in rodents was also reported (Rosenfeld $\mathrm{J}$ et al., 2003), although with uncertainty of its binding site on the CES promoter region. It was not considered as a circadian gene originally; 
however, more recent evidences pointed at the opposite direct. For example, Montagner A et al. (2016) showed that even though the change of PXR was not profound, the downstream gene target of PXR was largely altered following a circadian pattern. Nevertheless, DEC1 was not considered as a regulator for CES until recently. In 2015, it was reported that mouse ces1d expression was regulated by a stra13-involved mechanism (Chen $\mathrm{R}$ et al., 2015), which is equivalent to human DEC1. Interestingly, DEC1 has been revealed to be involved in the regulation of hepatic circadian clock by suppressing CLOCK/BMAL1-enhanced promoter activity (Nakashima A et al., 2008). Therefore, because the expression of CES can potentially altered through the treatment, the time of taking SOF should also be considered to avoid stronger drug-drug interactions.

In summary, our studies have led to several important findings. First of all, we have shown that SOF, but not its metabolites, irreversibly inhibited human CES2 but not CES1, suggesting that SOF is a specific CES2 inhibitor. Moreover, this inhibition is possibly caused allosterically, leading to a change in 3D shape of the active pocket and thus resulting in the lost of hydrolytic activity. Finally, such inhibition caused by SOF has a significant impact on drug metabolism and drug-drug interactions, requiring closer clinical monitors for patients taking SOF.

\section{Conflict of interest}


The authors declare that there are no conflict of interest.

\section{Acknowledgment}

This work is supported by NIH grants R01GM61988, R01EB018748 and R15AT007705

\section{References}

Barakat KH, Law J, Prunotto A, Magee WC, Evans DH, Tyrrell DL, Tuszynski J, Houghton M. Detailed computational study of the active site of the hepatitis C viral RNA polymerase to aid novel drug design. Journal of chemical information and modeling. 2013 Oct 24;53(11):3031-43.

Bencharit S, Morton CL, Howard-Williams EL, Danks MK, Potter PM, Redinbo MR.Structural insights into CPT-11 activation by mammalian carboxylesterases.Nature Structural and Molecular Biology. 2002 May;9(5):337-42.

Bertilsson G, Heidrich J, Svensson K, Åsman M, Jendeberg L, Sydow-Bäckman M, Ohlsson R, Postlind H, Blomquist P, Berkenstam A. Identification of a human nuclear receptor defines a new signaling pathway for CYP3A induction. Proceedings of the National Academy of Sciences. 1998 Oct 13;95(21):12208-13. 
Bunnell KL, Vibhakar S, Glowacki RC, Gallagher MA, Osei AM, Huhn G. Nephrotoxicity Associated with Concomitant Use of Ledipasvir-Sofosbuvir and Tenofovir in a Patient with Hepatitis C Virus and Human Immunodeficiency Virus Coinfection. Pharmacotherapy: The Journal of Human Pharmacology and Drug Therapy. 2016 Sep 1;36(9).

Bunnell KL, Vibhakar S, Glowacki RC, Gallagher MA, Osei AM, Huhn G. Nephrotoxicity Associated with Concomitant Use of Ledipasvir-Sofosbuvir and Tenofovir in a Patient with Hepatitis C Virus and Human Immunodeficiency Virus Coinfection. Pharmacotherapy: The Journal of Human Pharmacology and Drug Therapy. 2016 Sep 1;36(9).

Chen R, Wang Y, Ning R, Hu J, Liu W, Xiong J, Wu L, Liu J, Hu G, Yang J. Decreased carboxylesterases expression and hydrolytic activity in type 2 diabetic mice through Akt/mTOR/HIF-1 a/Stra13 pathway. Xenobiotica. 2015 Sep $2 ; 45(9): 782-93$.

Clark JL, Hollecker L, Mason JC, Stuyver LJ, Tharnish PM, Lostia S, McBrayer TR, Schinazi RF, Watanabe KA, Otto MJ, Furman PA. Design, synthesis, and antiviral activity of 2 '-deoxy-2 '-fluoro-2 '-C-methylcytidine, a potent inhibitor of hepatitis C virus replication. Journal of medicinal chemistry. 2005 Aug 25;48(17):5504-8.

Clark JL, Mason JC, Hollecker L, Stuyver LJ, Tharnish PM, McBrayer TR, Otto MJ, Furman PA, Schinazi RF, Watanabe KA. Synthesis and antiviral activity of 2'-deoxy-2'-fluoro-2'-C-methyl purine nucleosides as inhibitors of hepatitis $\mathrm{C}$ virus RNA replication. Bioorganic \& medicinal chemistry letters. 2006 Mar $15 ; 16(6): 1712-5$. 
Dassault Systèmes BIOVIA, Discovery Studio Modeling Environment, Release 2017, San Diego: Dassault Systèmes, 2016.

Dyson JK, Hutchinson J, Harrison L, Rotimi O, Tiniakos D, Foster GR, Aldersley MA, McPherson S. Liver toxicity associated with sofosbuvir, an NS5A inhibitor and ribavirin use. Journal of hepatology. 2016 Jan 31;64(1):234-8.

Ercolani G, Grazi GL, Callivà R, Pierangeli F, Cescon M, Cavallari A, Mazziotti A. The lidocaine (MEGX) test as an index of hepatic function: its clinical usefulness in liver surgery. Surgery. 2000 Apr 30;127(4):464-71.

Hemmert AC, Otto TC, Wierdl M, Edwards CC, Fleming CD, MacDonald M, Cashman JR, Potter PM, Cerasoli DM, Redinbo MR. Human carboxylesterase 1 stereoselectively binds the nerve agent cyclosarin and spontaneously hydrolyzes the nerve agent sarin. Molecular pharmacology. 2010 Apr 1;77(4):508-16.

Humerickhouse R, Lohrbach K, Li L, Bosron WF, Dolan ME. Characterization of CPT-11 hydrolysis by human liver carboxylesterase isoforms hCE-1 and hCE-2. Cancer Research. 2000 Mar 1;60(5):1189-92.

Kirby BJ, Symonds WT, Kearney BP, Mathias AA. Pharmacokinetic, pharmacodynamic, and drug-interaction profile of the hepatitis C virus NS5B polymerase inhibitor sofosbuvir. Clinical pharmacokinetics. 2015 Jul 1;54(7):677-90.

Kumari R, Nguyen MH. Fixed-dose combination of sofosbuvir and ledipasvir for the treatment of chronic hepatitis C genotype 1. Expert opinion on pharmacotherapy. 2015 Mar 24;16(5):739-48. 
Lam AM, Murakami E, Espiritu C, Steuer HM, Niu C, Keilman M, Bao H, Zennou V, Bourne N, Julander JG, Morrey JD. PSI-7851, a pronucleotide of $\beta$-D-2'-deoxy-2'-fluoro-2'-C-methyluridine monophosphate, is a potent and pan-genotype inhibitor of hepatitis $\mathrm{C}$ virus replication. Antimicrobial agents and chemotherapy. 2010 Aug 1;54(8):3187-96.

Lebrecht D, Venhoff AC, Kirschner J, Wiech T, Venhoff N, Walker UA. Mitochondrial tubulopathy in tenofovir disoproxil fumarate-treated rats. JAIDS Journal of Acquired Immune Deficiency Syndromes. 2009 Jul 1;51(3):258-63.

Lindenbach BD, Rice CM. Unravelling hepatitis C virus replication from genome to function. Nature. 2005 Aug 18;436(7053):933.

Mann JF, Schmieder RE, McQueen M, Dyal L, Schumacher H, Pogue J, Wang X, Maggioni A, Budaj A, Chaithiraphan S, Dickstein K. Renal outcomes with telmisartan, ramipril, or both, in people at high vascular risk (the ONTARGET study): a multicentre, randomised, double-blind, controlled trial. The Lancet. 2008 Aug 22;372(9638):547-53.

Marchan-Lopez A, Dominguez-Dominguez L, Kessler-Saiz P, Jarrin-Estupiñan ME. Liver failure in human immunodeficiency virus-Hepatitis $\mathrm{C}$ virus coinfection treated with sofosbuvir, ledipasvir and antiretroviral therapy. Journal of hepatology. 2016 Mar 1;64(3):752-3.

Mohd Hanafiah K, Groeger J, Flaxman AD, Wiersma ST. Global epidemiology of hepatitis C virus infection: New estimates of age-specific antibody to HCV seroprevalence. Hepatology. 2013 Apr 1;57(4):1333-42. 
Montagner A, Korecka A, Polizzi A, Lippi Y, Blum Y, Canlet C, Tremblay-Franco M, Gautier-Stein A, Burcelin R, Yen YC, Je HS. Hepatic circadian clock oscillators and nuclear receptors integrate microbiome-derived signals. Scientific reports. $2016 ; 6$.

Morris GM, Huey R, Lindstrom W, Sanner MF, Belew RK, Goodsell DS, Olson AJ.AutoDock4 and AutoDockTools4: Automated docking with selective receptor flexibility. Journal of Computational Chemistry. 2009 Dec;30(16):2785-91.

Moyle G. Mechanisms of HIV and nucleoside reverse transcriptase inhibitor injury to mitochondria. Antiviral therapy. 2005;10:M47-52.

Murakami E, Tolstykh T, Bao H, Niu C, Steuer HM, Bao D, Chang W, Espiritu C, Bansal S, Lam AM, Otto MJ. Mechanism of activation of PSI-7851 and its diastereoisomer PSI-7977. Journal of biological chemistry. 2010 Nov 5;285(45):34337-47.

Nakashima A, Kawamoto T, Honda KK, Ueshima T, Noshiro M, Iwata T, Fujimoto K, Kubo H, Honma S, Yorioka N, Kohno N. DEC1 modulates the circadian phase of clock gene expression. Molecular and cellular biology. 2008 Jun $15 ; 28(12): 4080-92$.

New Zealand Medsafe, Harvoni Data Sheet, 2017

Pettersen EF, Goddard TD, Huang CC, Couch GS, Greenblatt DM, Meng EC, Ferrin TE. UCSF Chimera--a visualization system for exploratory research and analysis. Journal of Computational Chemistry. 2004 Oct;25(13):1605-12.

Platt L, Easterbrook P, Gower E, McDonald B, Sabin K, McGowan C, Yanny I, Razavi H, Vickerman P. Prevalence and burden of HCV co-infection in people 
living with HIV: a global systematic review and meta-analysis. The Lancet infectious diseases. $2016 \mathrm{Jul}$ 31;16(7):797-808.

Rosenfeld JM, Vargas Jr R, Xie W, Evans RM. Genetic profiling defines the xenobiotic gene network controlled by the nuclear receptor pregnane $\mathrm{X}$ receptor. Molecular endocrinology. 2003 Jul 1;17(7):1268-82.

Shang W, Liu J, Chen R, Ning R, Xiong J, Liu W, Mao Z, Hu G, Yang J. Fluoxetine reduces ces1, ces2, and cyp3a4 expression through decreasing pxr and increasing dec1 in hepg2 cells. Xenobiotica. 2016 May 3;46(5):393-405.

Shen Y, Yan B. Covalent inhibition of carboxylesterase-2 by sofosbuvir and its effect on the hydrolytic activation of tenofovir disoproxil. Journal of hepatology. 2017 Mar 1;66(3):660-1.

Shi J, Wang X, Nguyen J, Wu AH, Bleske BE, Zhu HJ. Sacubitril is selectively activated by carboxylesterase 1 (CES1) in the liver and the activation is affected by CES1 genetic variation. Drug Metabolism and Disposition. 2016 Apr $1 ; 44(4): 554-9$.

Tang M, Mukundan M, Yang J, Charpentier N, LeCluyse EL, Black C, Yang D, Shi D, Yan B. Antiplatelet agents aspirin and clopidogrel are hydrolyzed by distinct carboxylesterases, and clopidogrel is transesterificated in the presence of ethyl alcohol. Journal of Pharmacology and Experimental Therapeutics. 2006 Dec 1;319(3):1467-76.

World Health Organization. Global Hepatitis Report 2017. 2017.

Xiao D, Shi D, Yang D, Barthel B, Koch TH, Yan B. Carboxylesterase-2 is a highly sensitive target of the antiobesity agent orlistat with profound implications in the 
activation of anticancer prodrugs. Biochemical pharmacology. 2013 Feb 1;85(3):439-47.

Zhu HJ, Markowitz JS. Activation of the antiviral prodrug oseltamivir is impaired by two newly identified carboxylesterase 1 variants. Drug Metabolism and Disposition. 2009 Feb 1;37(2):264-7. 
A

Inhibition of mouse microsomes

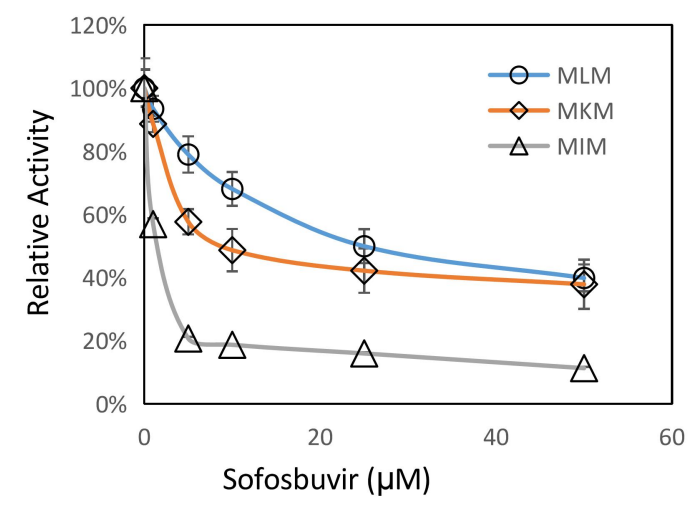

B

Inhibition of rat microsomes

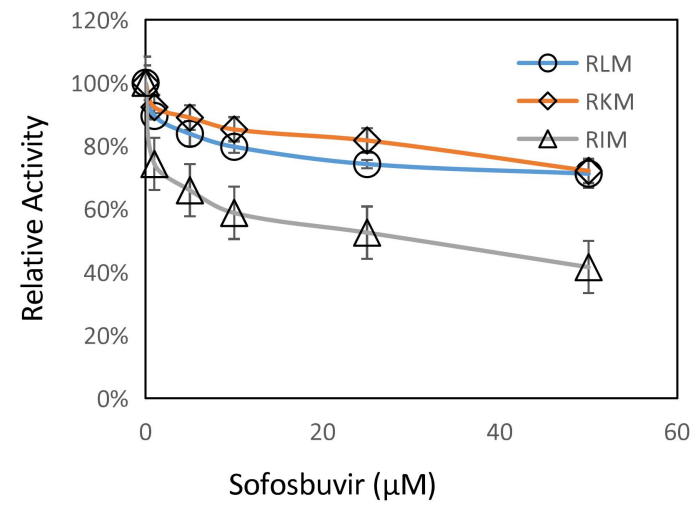

C

Mouse microsome native gel

\begin{tabular}{l|l|l}
\hline Liver & Kidney & Intestine
\end{tabular}
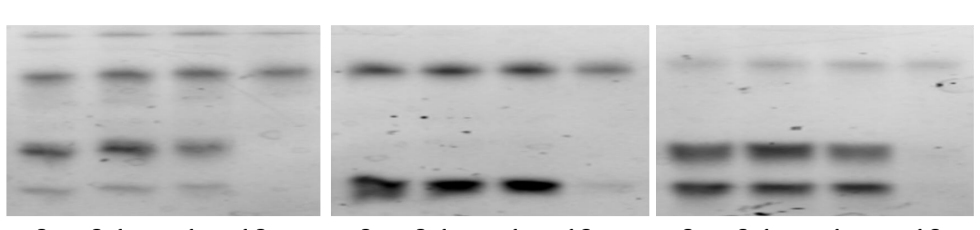

ces1d

ces1e

ces2e

ces $2 c$

\begin{tabular}{llllllllllll}
0 & 0.1 & 1 & 10 & 0 & 0.1 & 1 & 10 & 0 & 0.1 & 1 & 10 \\
\hline & \multicolumn{1}{c}{ Sofosbuvir $(\mu \mathrm{M})$}
\end{tabular}

D

Rat microsome native gel

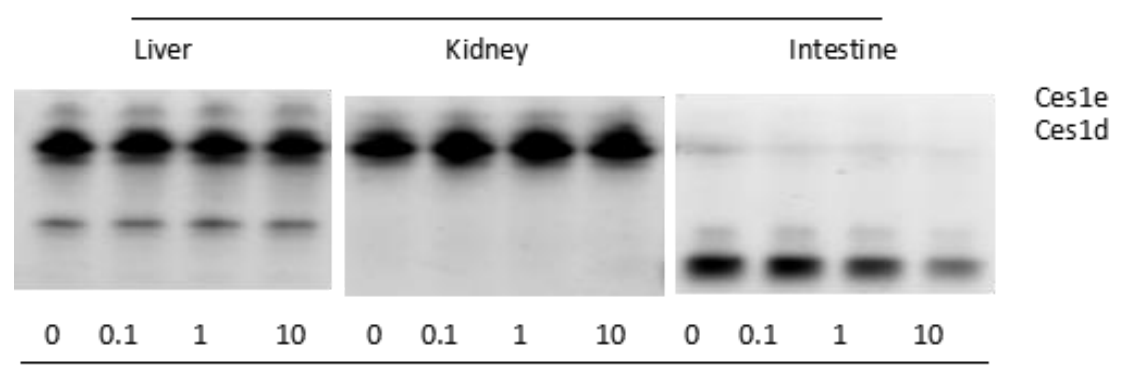

Sofosbuvir $(\mu \mathrm{M})$

Figure 1. Inhibition of carboxylesterase in mouse and rat microsomes. (A) Mouse liver (MLM), kidney (MKM) and intestine (MIM) microsomes were incubated with different concentrations of SOF for 2hr. (B) Rat liver (RLM), kidney (RKM) and intestine (RIM) microsomes were incubated with different concentrations of SOF for $2 \mathrm{hr}$. The enzyme activities in (A) and (B) were measured by the hydrolysis rate of nitrophenyl acetate. (C) Mouse liver, kidney and intestine microsomes were incubated with $0.1,1$ or $10 \mu \mathrm{M}$ of SOF for $2 \mathrm{hr}$ and then were subjected to native gel electrophoresis. (D) Rat liver, kidney and intestine microsomes were incubated with $0.1,1$ or $10 \mu \mathrm{M}$ of SOF for $2 \mathrm{hr}$ and then were subjected to native gel electrophoresis. The gels of (C) and (D) were then incubated with 4-methylumbelliferyl acetate and 1-naphthyl acetate for activity analysis. 
A Mouse carboxylesterases activity

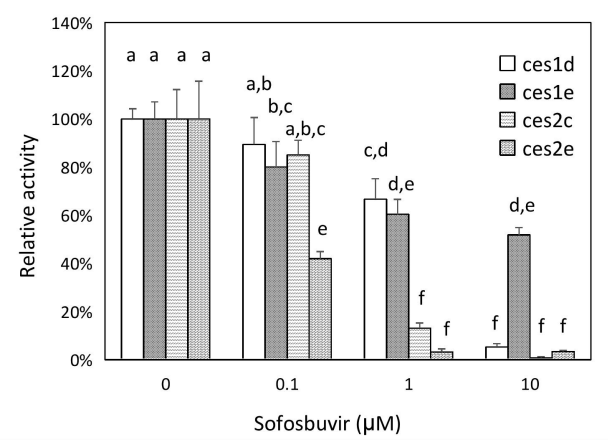

B Rat carboxylesterases activity

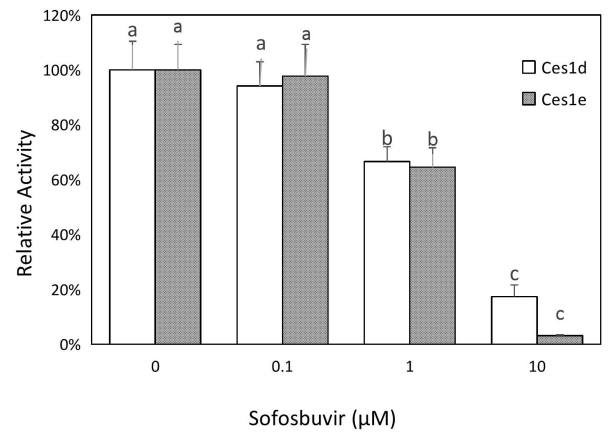

C Human carboxylesterases activity

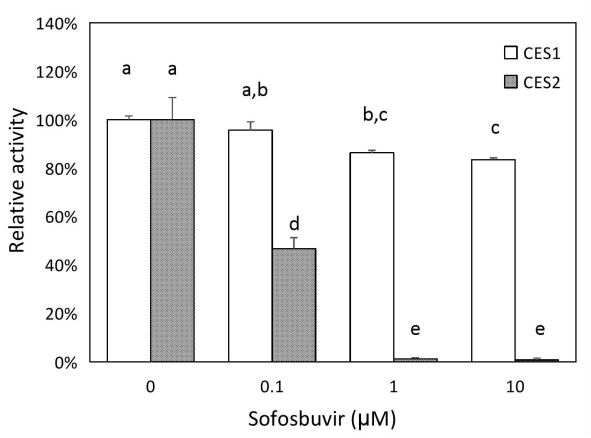

Figure 2. Inhibition of SOF toward recombinant proteins. Mouse (A), rat (B) and human (C) recombinant carboxylesterases were incubated with $0.1,1$ or $10 \mu \mathrm{M}$ for $2 \mathrm{hr}$, and then the enzyme activities were measured by the hydrolysis rate of nitrophenyl acetate. The statistics were calculated by SAS through Posthoc-ANOVA $(\mathrm{p}<0.05)$. 
A

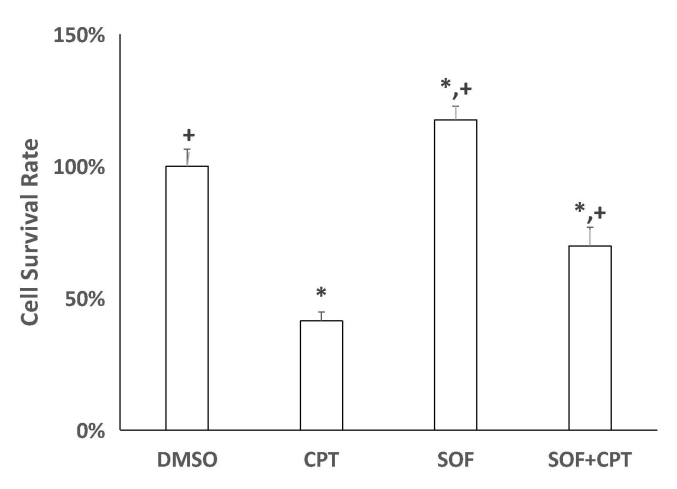

B
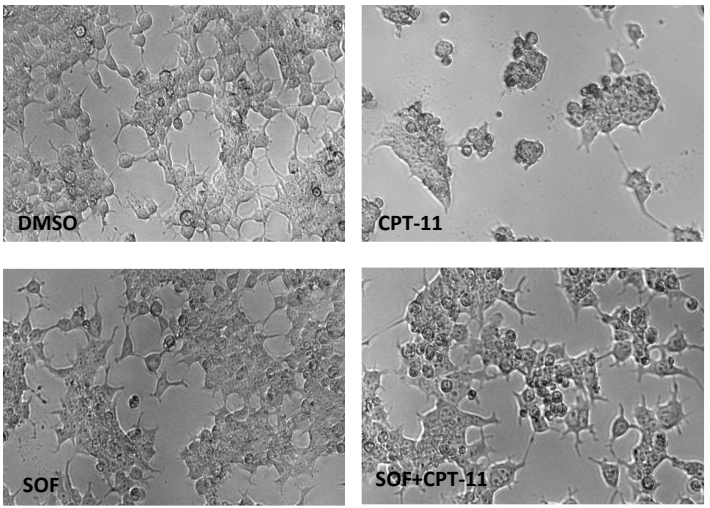

Figure 3. Cytotoxicity change caused by SOF. HEK-293 Cells transiently transfected with human CES2 plasmids were treated with $3 \mu \mathrm{M}$ CPT-11 alone or together with $10 \mu \mathrm{M}$ SOF. (A) The cell survival rate measured by MTT assay. (B) cell morphology images (20X). The statistics was calculated by SAS through Posthoc-ANOVA $(\mathrm{p}<0.05, *$ represent significant difference from DMSO treatment, and + represents significant difference from CPT-11 treatment). 
A

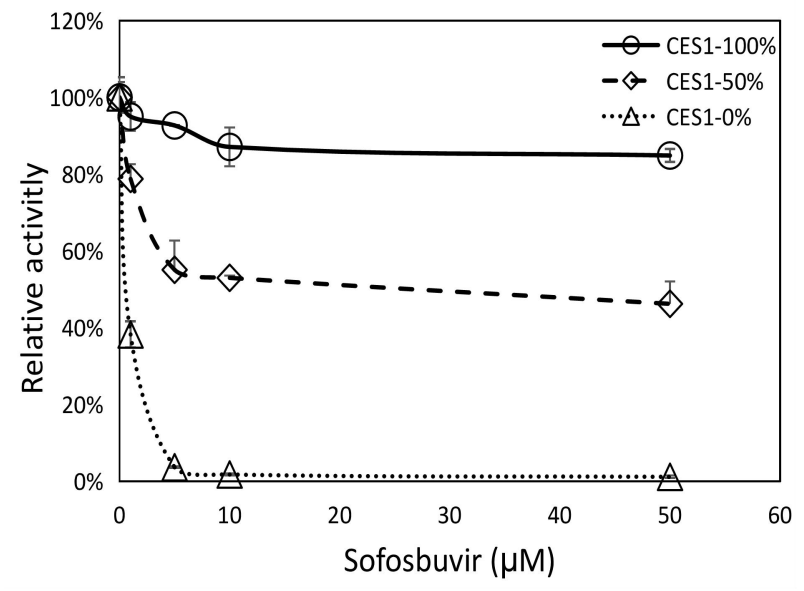

C

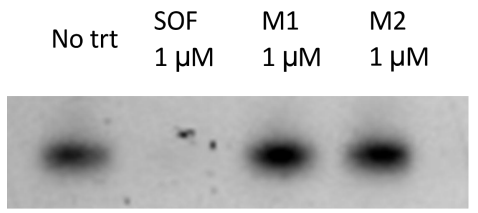

CES2

D

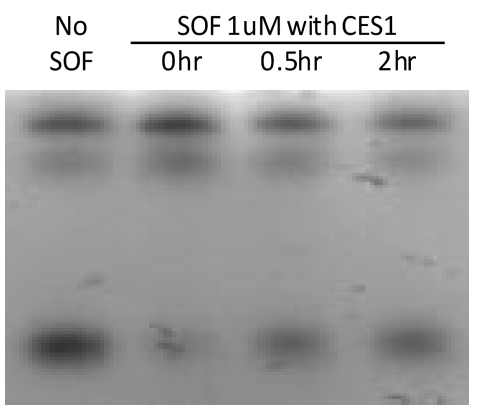

CES1

CES2
B

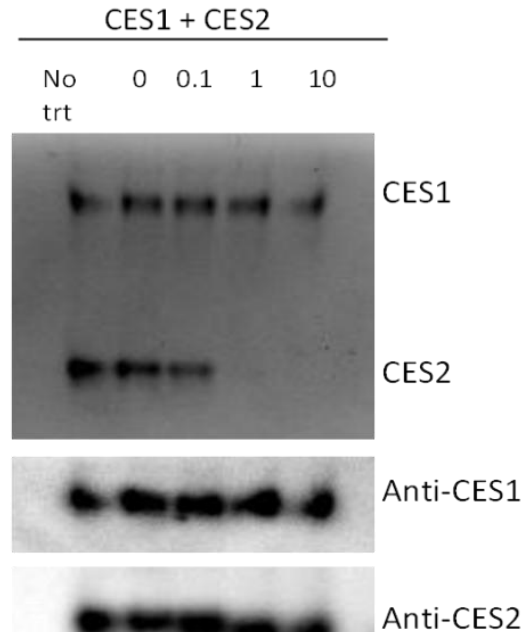

E

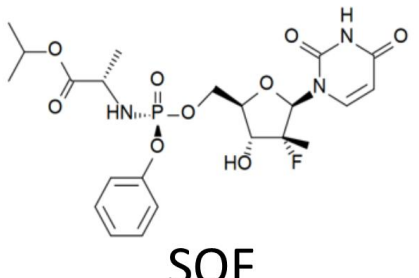

SOF

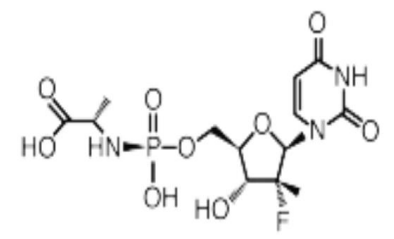

M1

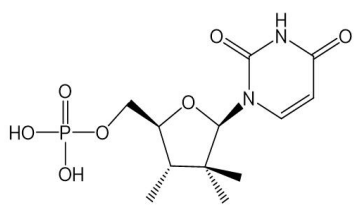

$\mathrm{M} 2$

Figure 4. SOF and metabolites inhibition on CES2. Human recombinant CES1 and CES2 were used for activity inhibition tests after incubation with SOF for 30min. (A) SOF inhibited CES2 activity activity in a dose-dependent manner in native gel electrophoresis, and only a slight inhibition of CES1 activity was observed at the highest concentration of SOF. (B) Nitrophenyl acetate hydrolysis analysis showed that the inhibition of the mixed enzyme activity was primarily caused by the inhibition of CES2. (C) The inhibition of CES2 activity was only achieved by SOF but not by its two major metabolites M1 and M2. (D) SOF inhibition on CES2 was decreased if SOF was pre-incubated with CES1 for at least 30min. (E) The metabolism of SOF. 

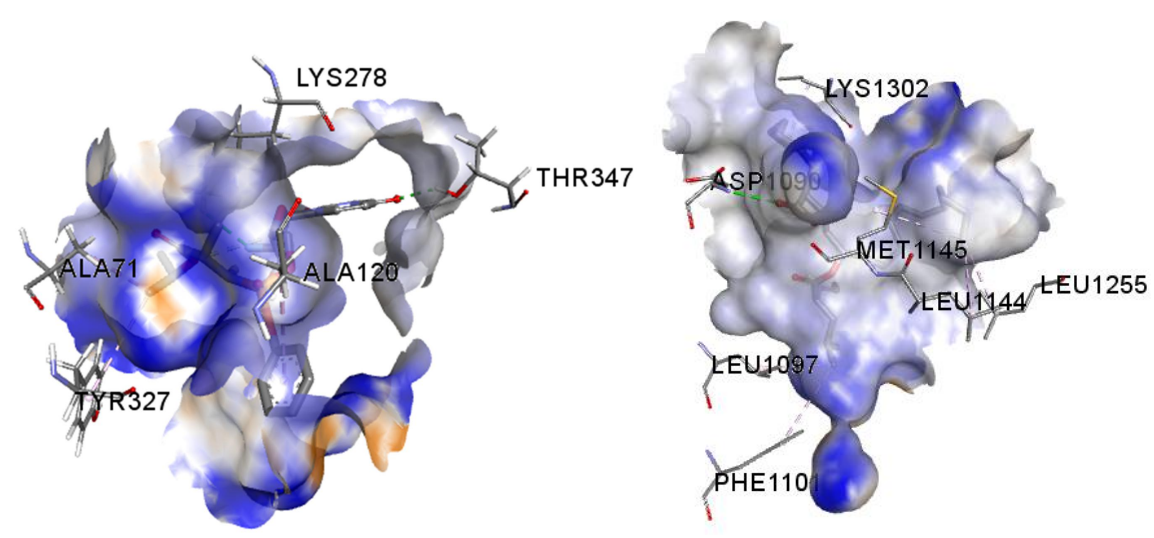

C Human, Mouse and Rat major CES precursor BLAST alignment (partial)

Human CES1

Mouse ces1d

Rat Ces1d

Mouse cesle

Rat Cesle

Human CES2

Mouse ces $2 e$

Mouse ces2c

Human CES1

Mouse ces1d

Rat Ces1d

Mouse cesle

Rat Cesle

Human CES2

Mouse ces2e

Mouse ces2c

Human CES1

Mouse ces1d

Rat Ces1d

Mouse cesle

Rat Cesle

Human CES2
154 GLALAAHENVVVVTIQYRLGIWGFFSTGDEHSRGNWGHLDQVAALRWVQDNIASFGGNPGSVTIFGESAGGESVSVLVLS

154 GLALSAHENVVVVTIQYRLGIWGFFSTGDEHSRGNWGHLDQVAALRWVQDNIANFGGNPGSVTIFGESAGGFSVSVLVLS

154 GOVLSAHENVVVVTIOYRLGIWGFFSTGDEHSOGNWGHLDQVAALHWVODNIANFGGNPGSVTIFGESAGGFSVSALVLS

155 GLVLSTHENVVVVVIQYRLGIWGFFSTGDEHSRGNWGHLDQVAALHWVQDNIAKFGGDPGSVTIFGESAGGESVSVLVLS

154 GLALSTHENVVVVVIQYRLGIWGFFSTGDEHSRGNWGHLDQVAALHWVQDNIDNFGGDPGSVTIFGESAGGESVSVLVLS

161 GSMLAALENVVVVIIOYRLGVLGFFSTGDKHATGNWGYLDQVAALRWVOQNIAHFGGNPDRVTIFGESAGGTSVSSLVVS

161 GSMLAATEDVVVVAIQYRLGVLGFFSTGDQHAKGNWGYLDQVAALRWVQQNIVHFGGNPDRVTIFGESAGGTSVSSHVVS

163 GSLLTVNEDLVVVTIQYRLGVLGFFSTGDQHARGNWGYLDQAAALRWVQQNIAHFGGNPDRVTIFGESAGGTSVSSHVVS

234 PLAKNLFHRAISESGVALTSVLVKKgDVKPLAEQIAITAGCKTTTSAVMVHCLRQKTEEELLETTLKMKFLSLDLQGDPR

234 PLAKNLFHRAISESGVSLTAALITT-DVKPIAGLVATLSGCKTTTSAVMVHCLRQKTEDELLETSLKLNLFKLDLLGNPK

234 PLAKNLFHRAISESGVVLTSALITT-DSKPIANLIATLSGCKTTTSAVMVHCLROKTEDELLETSLKLNLFKLDLLGNPK

235 PLAKNLFQRAISESGVALTAGLVKK-NTRPLAEKIAVISGCKNTTSAAMVHCLRQKTEEELLGTTLKLNLFKLDLHGDSR

234 PLAKNLFHKAISESGVALTAGLVKK -NTRPLAEKIAVVSGCKSTTSASMVHCLROKTEEELLETTLKLNLFSLDLHGDSR

241 PISOGLFHGAIMESGVALLPGLIAS-SADVISTVVANLSACDQVDSEALVGCLRGKSKEEILAIN

241 PMSQGLFHGAIMESGVAVLPDLISS-SSEMVHRIVANLSGCAAVNSETLMCCLRGKNEAEMLAIN

243

PMSQGLFHGAIMESGVALLPDLISE - TSEMVSTTVAKLSGCEAMDSQALVRCLRGKSEAE ILAIN - . . . . .

ESQPLLGTVIDGMLLLKTPEELQAERNFHTVPYMVGINKQEFGWLIPMQLMSYPLSEGQLDQKTAMSLLWKSYPLVCIAK ESYPFLPTVIDGVVLPKAPEE I LAEKSFSTVPYIVGINKQEFGWI IPT - LMGYPLAEGKLDQKTANSLLWKSYPTLKISE ESYPFLPTVIDGVVLPKTPEE ILAEKSFNTVPYIVGINKQEFGWI IPT - LMGYPLSEGKLDQKTAKSLLWKSYPTLKISE QSHPFVPTVLDGVLLPKMPEE ILAEKNFNTVPYIVGINKQEFGWILPT-MMNYPPSDVKLDQMTAMSLLKKSSFLLNLPE QSYPFVPTVLDGVVLPKMPEE I LAEKDFNTVPYIVGINKOEFGWILPT-MMNYPPSDMKLDPMTATSLLKKSSFLLNLPE KPFKMIPGVVDGVFLPRHPQELLASADFQPVPSIVGVNNNEFGWLIPK - VMRIYDTQKEMDREASQAALQKMLTLLMLPP
233

233

234

233

240

240

242

313

Figure 5. SOF docking profile on CES1 and CES2. SOF were docked with human CES2 homology model (A) and human CES1 structure (B). (C) The comparison of human, mouse and rat carboxylesterases. 


\title{
Manuscript 3
}

Tenofovil alafenamide and tenofovir disoprosxil induced lipid accumulation in Huh7 cells through their regulation on small heterodimer partner with interactions of ethyl alcohol

\author{
Yuanjun Shen ${ }^{1}$, Karen $\mathrm{Ho}^{2}$, Xiaodong Wang ${ }^{3}$, Bingfang Yan*
}

Biomedical and Pharmaceutical Sciences, University of Rhode Island, Kingston, RI, USA

1. PhD Candidate, College of Pharmacy, University of Rhode Island, Kingston, RI 02881

2. Post Doctoral Fellow, College of Pharmacy, University of Rhode Island, Kingston, RI 02881

3. College of Pharmacy, University of Rhode Island, Kingston, RI 20881

4. Professor, College of Pharmacy, University of Rhode Island, Kingston, RI 02881 


\begin{abstract}
Tenofovir disoproxil fumarate (TDF) and tenofovir alafenamide fumarate (TAF) are prodrugs for tenofovir (TFV) in the therapies of Hepatitis B Virus (HBV) infections and Human Immunodeficiency Virus (HIV) infections. Both of them need to be monitored for severe hepatomegaly with steatosis. Although TDF was found to have mitochondria-depletion induced lipid metabolism dysfunction, it was not true for TAF. Therefore, this study was designed in an attempt to discover a possible explanation. Results indicate that both TAF and TDF lead to lipid retention in Huh7 cells, concomitant with the induction of small heterodimer partner (SHP) expression of both mRNA and protein. Further experiments demonstrated that it was the prodrugs but not TFV that led to the lipid retention and SHP induction. Moreover, TAF also showed a synergic lipid retention effect with ethanol $(\mathrm{EtOH})$ co-treatment, possibly caused by the CES1-mediated ethyl transesterification pathway.
\end{abstract}

\title{
Introduction
}

Hepatitis B Virus (HBV) infections and Human Immunodeficiency Virus (HIV) infections are two of the most significant global epidemic diseases. World Health Organization estimated 257 million HBV carriers and 26.7 million HIV carriers globally in 2017 (WHO). There are also about 2.7 million patients diagnosed with co-infection of both HBV and HIV. Although HBV belongs to Orthohepadnavirus while HIV belongs to Retrovirus, both infections can be inhibited by tenofovir (TFV), which is on the WHO List of Essential Medicines (van Bömmel F et al., 2002; Mulato AS and Cherrington JM, 1997). TFV functions as a nucleotide analogue in HBV 
therapy, while it is also a nucleotide reverse transcriptase inhibitor (NtRTI) in HIV therapy. However, the poor permeability of TFV due to the two negative charges limited its clinical use (JP Shaw et al., 1997), and, therefore, prodrugs of TFV have been developed to improve its pharmacokinetics profile. TFV disoproxil fumarate (TDF) and TFV alafenamide fumarate (TAF) are two of the successful oral prodrugs. TDF, commercially Viread, has been approved for treatment of both chronic HBV infection and HIV-1 infection (Viread, FDA, 2012); on the other hand, TAF, commercially Vemlidy, is only approved for HBV treatment but not recommended for HIV-1, which is because of its risk to enhance development of HIV resistance (Vemlidy, FDA, 2017). Both reagents are formed as an ester structure so as to increase the permeability. TAF and TDF can be hydrolyzed both by Cathepsin A (CatA) in peripheral blood mononuclear cell (PBMC) or carboxylesterase (CES) in liver (Birkus $\mathrm{G}$ et al., 2016), and the hydrolysis of the esters releases their parent compound, TFV, which is further metabolized into the active format, TFV-diphosphate (TFV-DP) (Balzarini J et al., 1998). However, use of both the approved drugs required clinical monitoring of severe hepatomegaly with steatosis.

Carboxylesterases (CES) belong to a family of hydrolases. The most abundant of CES in human tissues are CES1 and CES2 (Bencharit et al., 2002), which are closely related to both drug metabolisms and lipid dispositions (Redinbo et al., 2003; Ruby MA et al. 2017). CES enzymes play a vital role in the activation of both TAF and TDF; however, the hydrolysis was reported to be responsible to renal and hepatic toxicity (Samuels R et al., 2017). Interestingly, CES1 has been suggested to be largely 
involved in lipid metabolism (Xiao D et al., 2012). Therefore, the drug disposition of TAF and TDF with the involvement of CES becomes increasingly important both for clinical monitoring and for future drug discoveries.

This study has been designed to broaden the understanding of the mechanisms of the lipid retention caused by TAF and TDF treatment in cells, including gene regulation and drug-drug interactions. It was found that both TAF and TDF were able to significantly increase lipid retention, especially in CES knockout cells prepared by the Clustered Regularly Interspaced Short Palindromic Repeats(CRISPR)/Cas9 transfection technique.

\section{Materials and methods}

\section{Chemicals and supplies}

Tenofovir disoproxil fumurate and tenofovir alafenamide fumurate were obtained from MedChemExpress (Monmouth Junction, NJ). Dulbecco's modified eagle medium (DMEM) was obtained from Life Technologies (Carlsbad, CA). The goat anti-rabbit IgG conjugated with horseradish peroxidase was obtained from Pierce (Rockford, IL). Nitrocellulose membranes were obtained from Bio-Rad (Hercules, CA). Unless otherwise specified, all other reagents were obtained from Fisher Scientific (Fair Lawn, NJ).

\section{Cell culture and treatment}


Huh7 cells were maintained in full growth medium (DMEM, 10\% FBS, 1X nonessential amino acid, and $1 \mathrm{X}$ penicillin/streptomycin). After seeded in plates or chamber slides, treatment agents were dissolved (1:1000) in 1\% delipid DMEM medium. Cells were either collected for protein and messenger RNA extraction after two days of TAF or TDF treatment, or stained with nile red and DAPI for lipid droplet fluorescent assay after one day of TAF or TDF treatment and another day of anti-viral and oleic acid co-treatment. Mouse primary hepatocytes were isolated from Balb-c mice through hepatic perfusion by William's Medium E (WME) with collagenase. Cells were separated by centrifugation with Percoll, and seeded with WME with insulin, transferrin, selenium (ITS) and dexamethasone (DEX). Seeded Human primary hepatocytes in 24 well plates were purchased from Thermo Fisher.

\section{CRISPR cell line preparation}

CRISPR/Cas9 plasmids were purchased from Santa Cruz (Dallas, TX) and their 20-nt sequences guiding RNA are presented in Table 1. The plasmids were transfected into Huh7 cells, and then cells were sorted by the cytofluorometry according to the expression of GFP conducted at Life Span. Inc (Providence, RI). Single colonies were then picked up after the sorting, and examined by SDS-PAGE or Native Gel Electrophoresis for the expressions of target proteins.

\section{Western blot}

Cell lysis was sonicated in Tris-HCl buffer $(\mathrm{pH} 7.4)$, and the same amount of total protein measured by commercial bicinchoninic acid assay were resolved by $7.5 \%$ 
SDS - polyacrylamide gel electrophoresis in a mini-gel apparatus (BioRad Laboratories, Hercules, CA) and transferred electrophoretically to nitrocellulose membranes. After nonspecific binding sites were blocked with 5\% nonfat milk, the blots were incubated with an antibody against human or mouse small heterodimer partner (SHP). The primary antibodies were subsequently localized with a secondary antibody conjugated with horseradish peroxidase. Horseradish peroxidase activity was detected with a chemiluminescent kit (SuperSignal West Pico; Pierce Chemical). The chemiluminescent signal was captured by MyECL Imager.

\section{Immunocytochemistry}

Huh7 cells $\left(4 \times 10^{4} /\right.$ well $)$ were seeded in four-well chamber slides. After two-day treatment, cells were rinsed in ice-cold PBS, and fixed by $4 \%$ formaldehyde in PBS for $10 \mathrm{~min}$. Fixed cells were then permeabilized and blocked by incubating with $0.1 \%$ Triton-X and 1\% BSA in PBS for $1 \mathrm{hr}$. SHP primary antibody (NR0B2 antibody, abx001518, Abbexa, Cambridge, UK) was dissolved 1:100 with 1\% BSA in PBS, and incubated with the cells overnight at $4^{\circ} \mathrm{C}$. Afterwards, Alexa Fluor ${ }^{\circledR} 488$ goat anti-rabbit IgG antibody $4 \mathrm{ug} / \mathrm{mL}$ (1:500) in PBS were incubated with cells and imaged at 10X and 20X by Invitrogen EVOS FL Auto Cell Imaging System.

\section{Lipid droplet fluorescent assay}

Huh7 cells 8000/well were seeded in 96-well clear bottom white microplates. After one day of treatment with TAF or TDF, cells were co-treated with anti-viral agents and $400 \mathrm{uM}$ oleic acid for another day. Cells were then fixed by $4 \%$ formaldehyde in 
PBS and stained by nile red and DAPI for imaging (Invitrogen EVOS FL Auto Cell Imaging System) as well as fluorescent signal measurements (SpectraMax M2 Multi-Mode Microplate Reader).

\section{Statistics}

Data are presented as mean $\pm \mathrm{SD}$ of at least three separate experiments. Statistical significance between two means was made by one-way ANOVA followed by a Tukey's HSD comparison test. Statistical analysis was performed by adopting R-Studio.

\section{Results}

TAF and TDF induced more lipid retention than TFV in Huh7 cells. It has been showed that chronic use of quite a few NtRTIs lead to mitochondrial damage, which may end up causing hepatic steatosis (Day L et al., 2004). TDF and TAF both potentially lead to severe hepatomegaly with steatosis (Viread lable, FDA, 2012; Vemlidy label, FDA, 2017). In this study, we managed to mimic the lipid retention in Huh7 cells following treatment with TDF or TAF. First of all, treatment of TFV, the metabolite, did not exhibit significant increase of lipid retention even at the highest concentration (Figure 1A) the lipid droplet microscopy also verified the reading results (Figure 1E). However, both TAF (Figure 1B and 1F) and TDF (Figure 1C and $1 G)$ showed strong elevation of lipid retention compared with control, which also exhibited in a dose dependent manner for both treatments. Interestingly, compared to 
DMSO treatment, TDF treatment in each concentration resulted in higher mean value of lipid retention readings than those from TAF treatments, although the statistic analysis showed similar trends.

\section{TAF and TDF increased SHP expression both on mRNA level and protein level.}

Tests were designed to determine the possible reason for the lipid retention. In 2006, it was reported that $o b / o b$ mice with $\mathrm{SHP}^{-/-}$had significantly lower lipids level compared with ob/ob groups (Huang J, 2006). Result here also suggest that both TAF and TDF treatments lead to a dose dependent mRNA and protein expression elevation of SHP, which was not observed in TFV treatment (Figure 2A-2C). The mRNA showed a moderate dose-dependent manner in TAF treatment, and the level did not show statistic difference until the concentration of TAF reached 10 $\mathrm{MM}$ (Figure 2B); in contrast, TDF showed more profound SHP mRNA elevation even at $5 \mu \mathrm{M}$ (Figure 2C). However, protein analysis showed that TAF treatment resulted in a more profound expression than TDF treatment. The immunocytochemistry results also strongly suggested that the treatments of TAF and TDF, but not TFV, lead to an increase of SHP expression around the nucleus (Figure 2D). Interestingly, It was clear that, in TAF treatment, SHP expressed mostly in nucleus, which overlapped nicely with DAPI staining, a dye that only stain the nucleus, but TDF treatment seemed to show a more diffused expression of SHP.

SHP played a vital role in lipid retention in Huh7 cells. To determine if the lipid retention in Huh7 cells was also regulated by SHP, Huh7 cells were transfected with 
SHP plasmids transiently and then treated with oleic acid for one day. The lipid droplet assay results showed there was a significant increase $(30 \%, \mathrm{p}<0.05)$ in SHP-transfected Huh7 cells compared with wild type cells (Figure 3A), which was also showed in the microscopy images (Figure 3B). These results confirmed that SHP played a vital role in the lipid accumulation effect in Huh7 cells.

The pro-drug, but not the metabolite, induced lipid retention. The direct TFV treatment showed no induction in lipid retention, nor did it regulate SHP expression; however, TFV was known to have poor cell membrane permeability (Shaw JP et al., 1997), which led to the development of the current two prodrugs. Therefore, experiments were designed with CRISPR CES-knockout (CES-KO) cell lines to test the effect of the prodrug metabolism in the cells on lipid accumulation profile. TAF treatment resulted in much higher lipid accumulations in CES1-KO cells (Figure 4B) compared with WT cells (Figure 4A) in all treatment concentrations; however, it was not that significant in CES2-KO cells (Figure 4C). On the other hand, TDF treatments resulted in higher lipid accumulation in both CES1-KO and CES2-KO cells (Figure 4D-4F); however, these increased lipid retention effects were less significant than those from TAF treatment in CES1-KO cells. These results reflect the fact that TAF was a substrate of CES1 but not CES2, while TDF was a substrate for both enzymes. Interestingly, CES2-KO cells exhibited higher base-line lipid retention than CES1-KO cells. 


\section{The cotreatment of TAF and ethyl alcohol lead to synergic lipid retention in}

Huh 7 cells. Ethanol $(200 \mathrm{mM})$ treatment in Huh7 cells generally caused $25 \%$ increase in lipid accumulation (Figure 5A-C). Additionally, similar to previous results, the increased concentrations of TAF resulted in a 3-36\% increase of lipid accumulation. Moreover, the co-treatment of TAF with ethanol lead to a 40-63.5\% increase in lipid accumulation, representing a synergic effect with a saturation from $5 \mu \mathrm{M}$ TAF treatment (Figure 5A-D). It is well known that CES1 not only functions as a hydrolase, but also functions as a transesterase when alcohol is involved (Brzezinski MR et al., 1997; Fleming CD et al., 2005; Hu ZY et al., 2014). In order to understand the possible mechanisms of this synergic effect, TAF, ethanol and liver microsomes from different species were co-incubated and the mixture was subjected to HPLC analysis. It was clear that all the three microsomes were able to generate a new peak (retention time $2.1 \mathrm{~min}$ ) apart from TAF (retention time 2.8min) and TFV (retention time $1.2 \mathrm{~min}$ ), especially from rat liver microsome. This new peak was hypothesized to be ethyl-transesterified TAF. It was also shown that CES1 family activity was higher in rat, than mouse and human (Figure 5E-G).

\section{Discussion}

Our current study is the first to illustrate the fact that it was the prodrugs, but not TFV, that caused profound lipid retention in Huh7 cells. Similar results were also observed in HepG2 and HC04 cell lines (data not shown). Instead of concluding that the prodrugs directly induced lipid retention through their up-regulation effects on human 
SHP, it is still highly possible to be related to the poor permeability of TFV. Taneva E et al. (2016) suggested that the permeability of TDF was $10^{4}$ folds higher than TFV, and was at least a 10-fold increase of drug uptake in tested cell lines than TFV as well. Studies showed that most of TAF and TDF molecules were able to pass the membrane through passive diffusion; however, TFV was primarily transported by human organic anion transporter (OAT)-1 and OAT-2, which required energy and exhibited less efficiency. A well known mechanisms of TFV toxicity is its capability to induce mitochondria dysfunction, which results in decreased mitochondria DNA (mtDNA), increased reactive oxygen species and decreased $\beta$-oxidation (Apostolova $\mathrm{N}$ et al., 2011). However, with a much higher permeability, TDF hydrolysis in mitochondria is predicted to be more efficient than the transportation of TFV from cytosol.

Lipid is efficiently oxidized by mitochondria in liver through $\beta$-oxidation. It was found that TDF treatment caused oxidative stress with increased measurements of thiobarbituric acid reacting substances (TBARS) and decreased reduced glutathione in rats (Abraham P et al., 2013). TDF treatment also showed to deplete mtDNA, which is essential for the formation of the respiratory chain (Samuels R et al., 2017). Both oxidative stress and mtDNA depletion were considered to be the reasons for reduced $\beta$-oxidation. Thus, the lipid retention induced by TFV prodrugs was first explained by their toxicity in mitochondria. However, Gilead scientists reported that TAF was not able to deplete mtDNA in human T-cell lines (Stray KM et al., 2017), although clinical reports also mentioned higher levels of all lipid fractions in TAF than in TDF 
treated human subjects (Sax PE et al., 2015). Therefore, it becomes increasingly important to understand mechanisms that lead to lipid retention other than mitochondria toxicity.

This is the first study to show that treatment with TAF and TDF, but not TFV, increases SHP expressions in both mRNA and protein levels. Although more studies need to be done to understand if it was the hydrolysis of prodrugs after their entry into the nucleus, or it is the prodrug themselves, that causes the up-regulation of SHP, it became clearer that such mechanisms could be added to the $\beta$-oxidation dysfunction theory for the explanation of lipid retention. Huang JS et al. (2007) reported that the over expression of SHP in $\mathrm{OB}^{-/-}$mice was the leading cause of hepatic steatosis. When SHP gene was knocked out from such mice, liver weight, lipid accumulation in tissue histological analysis, and hepatic triglycerides were all significantly decreased. Further research from the same lab also revealed that SHP correlated with neuronal PAS domain-containing protein 2 (NPAS2) in mice in lipid metabolism regulation (Lee SM et al., 2015). Other research also indicated that the involvement of farnesoid $\mathrm{X}$ receptor (FXR) together with SHP in the regulation of lipid metabolisms (Kim KH et al., 2017). It is not clear about the mechanisms of lipid regulation by SHP, but the increase of SHP by TAF and TDF from our study was highly related to the lipid retention observed in Huh7 cells. More importantly, such up-regulation of SHP was more profoundly and steadily observed when cells were treated with TAF than with TDF in all type of cells that we adopted, which also explained why TAF therapy also caused steatosis without reported function in mtDNA depletion. 
Additionally, alcohol consumption is also a great concern for HIV patients. In 2014, a group of researchers reported that $62.9 \%$ of the HIV patients with certain anti-virus treatment were reported to have worse medical problems caused by drinking (Elliott JC et al., 2014). Likewise, a systematic review also indicated that $77 \%$ of the studies showed negative impact on HIV therapy by alcohol use, in which 14 out of 17 studies focused on alcohol consumption and HIV suppression also concluded in a negative association (Vagenas P et al., 2015). Interestingly, alcohol not only caused toxicity in liver and kidneys, but also played very important roles in drug metabolism. Reports has shown that CES1 was able to catalyze its substrate, with the existence of ethyl alcohol, into an ethyl ester. For example, methylphenidate, a CES1 substrate for attention-deficit/hyperactivity disorder therapy,if taken by adolescent with alcohol abuse, was transesterified into ethylphenidate (Patrick KS et al., 2014). Other CES1 substrates were also found to be ethyl transesterified with alcohol consumption, such as cocaine and cocaethylene (Brzezinski MR et al., 1997), fatty acids and fatty acyl ethyl esters (Fleming CD et al., 2005), and clopidogrel and ethyl clopidogrel (Hu ZY et al., 2014). Similarly, our research also showed that TAF, while co-incubated with ethanol, can be potentially transesterified by liver microsomes, where abundant CES1 was expressed. Although the pharmacological effect of possible ethyl-TAF was not clear, it is very likely that this hypothesized ethyl-TAF may be involved in lipid metabolism dysfunction. However, more research need to be done to verify the structure of the molecule and its pharmacological effects as well. It is also interesting to notice that the ethyl-ester transesterification effects were comparable between 
mouse and human liver microsome, but not rat, indicating a possible animal model for in vivo studies.

In conclusion, TAF and TDF exhibited potent lipid retention activity through the up-regulation of SHP both in mRNA and in protein level, which could be synerically enhanced with ethyl alcohol.

\section{Conflict of interest}

The authors declare that there are no conflict of interest.

\section{Acknowledgment}

This work is supported by NIH grants R01GM61988, R01EB018748 and R15AT007705

\section{References}

Abraham P, Ramamoorthy H, Isaac B. Depletion of the cellular antioxidant system contributes to tenofovir disoproxil fumarate-induced mitochondrial damage and increased oxido-nitrosative stress in the kidney. Journal of biomedical science. 2013 Aug 19;20(1):61. 
Apostolova N, Blas-Garcia A, V Esplugues J. Mitochondria sentencing about cellular life and death: a matter of oxidative stress. Current pharmaceutical design. 2011 Dec 1;17(36):4047-60.

Balzarini J, Naesens L, De Clercq E. New antivirals-mechanism of action and resistance development. Current opinion in microbiology. 1998 Oct 1;1(5):535-46.

Bencharit S, Morton CL, Howard-Williams EL, Danks MK, Potter PM, Redinbo MR.Structural insights into CPT-11 activation by mammalian carboxylesterases.Nature Structural and Molecular Biology. 2002 May;9(5):337-42.

Birkus G, Bam RA, Willkom M, Frey CR, Tsai L, Stray KM, Yant SR, Cihlar T. Intracellular activation of tenofovir alafenamide and the effect of viral and host protease inhibitors. Antimicrobial agents and chemotherapy. 2016 Jan 1;60(1):316-22.

Brzezinski MR, Spink BJ, Dean RA, Berkman CE, Cashman JR, Bosron WF. Human liver carboxylesterase hCE-1: binding specificity for cocaine, heroin, and their metabolites and analogs. Drug Metabolism and Disposition. 1997 Sep 1;25(9):1089-96.

Dassault Systèmes BIOVIA, Discovery Studio Modeling Environment, Release 2017, San Diego: Dassault Systèmes, 2016.

Day L, Shikuma C, Gerschenson M. Mitochondrial injury in the pathogenesis of antiretroviral-induced hepatic steatosis and lactic acidemia. Mitochondrion. 2004 Jul 31;4(2):95-109.

Elliott JC, Aharonovich E, O'leary A, Johnston B, Hasin DS. Perceived medical risks of drinking, alcohol consumption, and hepatitis $\mathrm{C}$ status among heavily drinking 
HIV primary care patients. Alcoholism: Clinical and Experimental Research. 2014 Dec 1;38(12):3052-9.

Fleming CD, Bencharit S, Edwards CC, Hyatt JL, Tsurkan L, Bai F, Fraga C, Morton CL, Howard-Williams EL, Potter PM, Redinbo MR. Structural insights into drug processing by human carboxylesterase 1: tamoxifen, mevastatin, and inhibition by benzil. Journal of molecular biology. 2005 Sep 9;352(1):165-77.

Food and Drug Administration and Gilead Sciences, Vemlidy Label, 2017

Food and Drug Administration and Gilead Sciences, Viread Label, 2012

Hemmert AC, Otto TC, Wierdl M, Edwards CC, Fleming CD, MacDonald M, Cashman JR, Potter PM, Cerasoli DM, Redinbo MR. Human carboxylesterase 1 stereoselectively binds the nerve agent cyclosarin and spontaneously hydrolyzes the nerve agent sarin. Molecular pharmacology. 2010 Apr 1;77(4):508-16.

Hu ZY, Laizure SC, Herring VL, Parker RB. Identification of alcohol-dependent clopidogrel metabolites using conventional liquid chromatography/triple quadrupole mass spectrometry. Rapid Communications in Mass Spectrometry. 2014 Jun 15;28(11):1285-92.

Hu ZY, Laizure SC, Herring VL, Parker RB. Identification of alcohol-dependent clopidogrel metabolites using conventional liquid chromatography/triple quadrupole mass spectrometry. Rapid Communications in Mass Spectrometry. 2014 Jun 15;28(11):1285-92.

Huang J, Iqbal J, Saha PK, Liu J, Chan L, Hussain MM, Moore DD, Wang L. Molecular characterization of the role of orphan receptor small heterodimer partner in development of fatty liver. Hepatology. 2007 Jul 1;46(1):147-57. 
Huang J, Tabbi-Anneni I, Gunda V, Wang L. Transcription factor Nrf2 regulates SHP and lipogenic gene expression in hepatic lipid metabolism. American Journal of Physiology-Gastrointestinal and Liver Physiology. 2010 Dec 1;299(6):G1211-21.

Kim KH, Choi S, Zhou Y, Kim EY, Lee JM, Saha PK, Anakk S, Moore DD. Hepatic FXR/SHP Axis Modulates Systemic Glucose and Fatty Acid Homeostasis in Aged Mice. Hepatology. 2017 Apr 1.

Lee SM, Zhang Y, Tsuchiya H, Smalling R, Jetten AM, Wang L. Small heterodimer partner/neuronal PAS domain protein 2 axis regulates the oscillation of liver lipid metabolism. Hepatology. 2015 Feb 1;61(2):497-505.

Morris GM, Huey R, Lindstrom W, Sanner MF, Belew RK, Goodsell DS, Olson AJ.AutoDock4 and AutoDockTools4: Automated docking with selective receptor flexibility. Journal of Computational Chemistry. 2009 Dec;30(16):2785-91.

Mulato AS, Cherrington JM. Anti-HIV activity of adefovir (PMEA) and PMPA in combination with antiretroviral compounds: in vitro analyses. Antiviral research. 1997 Oct 31;36(2):91-7.

Patrick KS, Corbin TR, Murphy CE. Ethylphenidate as a selective dopaminergic agonist and methylphenidate-ethanol transesterification biomarker. Journal of pharmaceutical sciences. 2014 Dec 1;103(12):3834-42.

Pettersen EF, Goddard TD, Huang CC, Couch GS, Greenblatt DM, Meng EC, Ferrin TE. UCSF Chimera--a visualization system for exploratory research and analysis. Journal of Computational Chemistry. 2004 Oct;25(13):1605-12.

Redinbo MR, Bencharit S, Potter PM. Human carboxylesterase 1: from drug metabolism to drug discovery. (2003): 620-624. 
Ruby MA, Massart J, Hunerdosse DM, Schönke M, Correia JC, Louie SM, Ruas JL, Näslund E, Nomura DK, Zierath JR. Human carboxylesterase 2 reverses obesity-induced diacylglycerol accumulation and glucose intolerance. Cell reports. 2017 Jan 17;18(3):636-46.

Samuels R, Bayerri CR, Sayer JA, Price DA, Payne BA. Tenofovir disoproxil fumarate-associated renal tubular dysfunction: noninvasive assessment of mitochondrial injury. AIDS (London, England). 2017 Jun 1;31(9):1297.

Sax PE, Wohl D, Yin MT, Post F, DeJesus E, Saag M, Pozniak A, Thompson M, Podzamczer D, Molina JM, Oka S. Tenofovir alafenamide versus tenofovir disoproxil fumarate, coformulated with elvitegravir, cobicistat, and emtricitabine, for initial treatment of HIV-1 infection: two randomised, double-blind, phase 3, non-inferiority trials. The Lancet. 2015 Jul 3;385(9987):2606-15.

Shaw JP, Sueoka CM, Oliyai R, Lee WA, Arimilli MN, Kim CU, Cundy KC. Metabolism and pharmacokinetics of novel oral prodrugs of 9-[(R)-2-(phosphonomethoxy) propyl] adenine (PMPA) in dogs. Pharmaceutical research. 1997 Dec 1;14(12):1824-9.

Stray KM, Park Y, Babusis D, Callebaut C, Cihlar T, Ray AS, Perron M. Tenofovir alafenamide (TAF) does not deplete mitochondrial DNA in human T-cell lines at intracellular concentrations exceeding clinically relevant drug exposures. Antiviral research. 2017 Apr 30;140:116-20.

Taneva E, Crooker K, Park SH, Su JT, Ott A, Cheshenko N, Szleifer I, Kiser PF, Frank B, Mesquita PM, Herold BC. Differential mechanisms of tenofovir and tenofovir disoproxil fumarate cellular transport and implications for topical 
preexposure prophylaxis. Antimicrobial agents and chemotherapy. 2016 Mar $1 ; 60(3): 1667-75$.

Vagenas P, Azar MM, Copenhaver MM, Springer SA, Molina PE, Altice FL. The impact of alcohol use and related disorders on the HIV Continuum of care: a systematic review. Current HIV/AIDS Reports. 2015 Dec 1;12(4):421-36.

van Bömmel F, Wünsche T, Schürmann $\mathrm{D}$, Berg $\mathrm{T}$. Tenofovir treatment in patients with lamivudine-resistant hepatitis B mutants strongly affects viral replication. Hepatology. 2002 Aug 1;36(2):507-8.

World Health Organization, (Oct 19th 2017) http://www.who.int/mediacentre/factsheets/fs204/en

Xiao D, Shi D, Yang D, Barthel B, Koch TH, Yan B. Carboxylesterase-2 is a highly sensitive target of the antiobesity agent orlistat with profound implications in the activation of anticancer prodrugs. Biochemical pharmacology. 2013 Feb 1;85(3):439-47. 
Table 1. Guiding RNA of CRISPR plasmids (Santa Cruz, Dallas, TX)

\begin{tabular}{|c|c|}
\hline Name & gRNA Sense sequence \\
\hline \multirow{3}{*}{ CES1 } & GTGCGGCATCAACCTATGAT \\
\cline { 2 - 2 } & TCACATCTGCTATCAAGTCC \\
\cline { 2 - 2 } CES2 & TGTTGTCCTGGACCCAGCGC \\
\hline \multirow{3}{*}{ SHP } & CCATGAAGGCTCTAACCTGC \\
\cline { 2 - 2 } & CCTCTTTACTCTTGCCCCGC \\
\hline & CAAAAACAAGCGCACCACCG \\
\cline { 2 - 2 } & CCCGTAGCCGCTGCCTATGT \\
\cline { 2 - 2 } & CGGGCCGGTGCTGCCTACAT \\
\hline
\end{tabular}




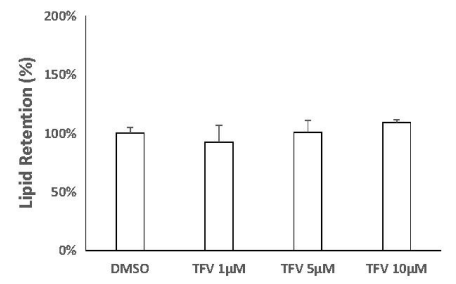

A

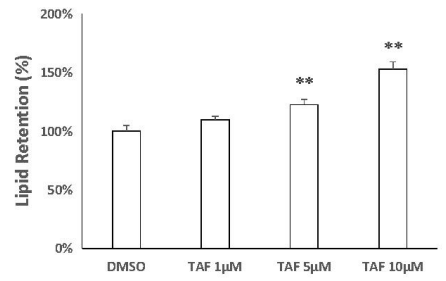

$\mathrm{B}$
E

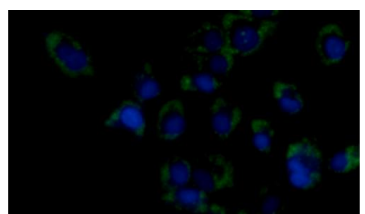

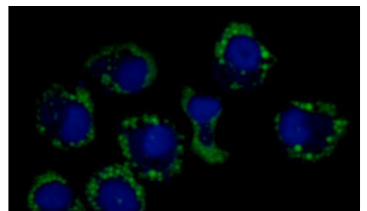

$\mathrm{F}$

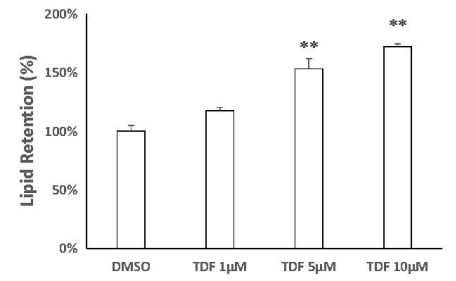

$\mathrm{C}$

Figure 1. Lipid retention in Huh7 cells by treating with TFV, TAF and TDF. Huh7 cells were seeded 8000/well in black 96-well plates with clear bottom. Cells were treated with different concentrations of TFV, TAF and TDF for the first day, and then were treated together with $400 \mu \mathrm{M}$ Oleic Acid for the second day. The cells were then fixed, washed by PBS, and stained by $5 \mu \mathrm{M}$ Nile red and $5 \mu \mathrm{M}$ DAPI. The fluorescence intensity was measured by plate reader and the images were taken by EVOS Microscope. (A) Lipid retention of TFV treatment is represented by fluorescence intensity. (B) Lipid retention of TAF treatment is represented by fluorescence intensity. (C) Lipid retention of TDF treatment is represented by fluorescence intensity. (D) Image of DMSO treatment. (E) Image of TFV 10uM treatment. (F) Image of TAF 10uM treatment. (G) Image of TDF 10uM treatment. The statistics was calculated by R-Studio through Post hoc - ANOVA (**represents $\mathrm{p}<0.01)$. 


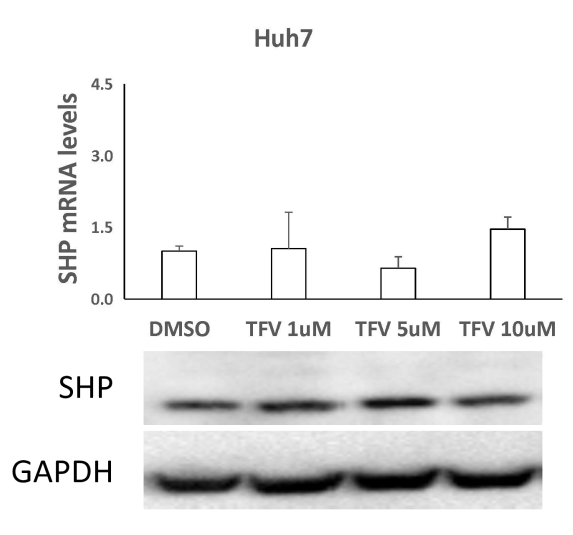

A

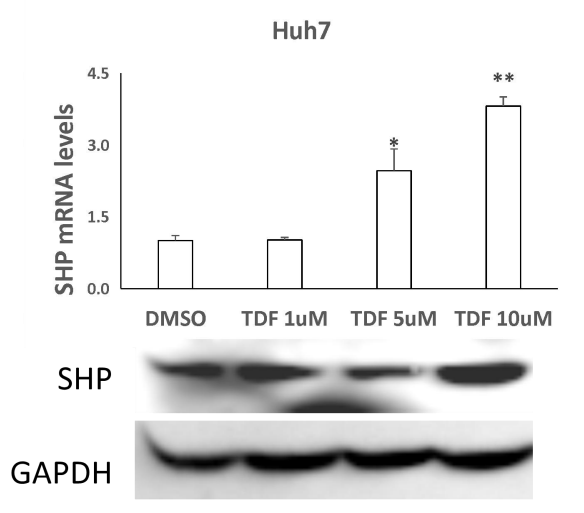

$\mathrm{C}$

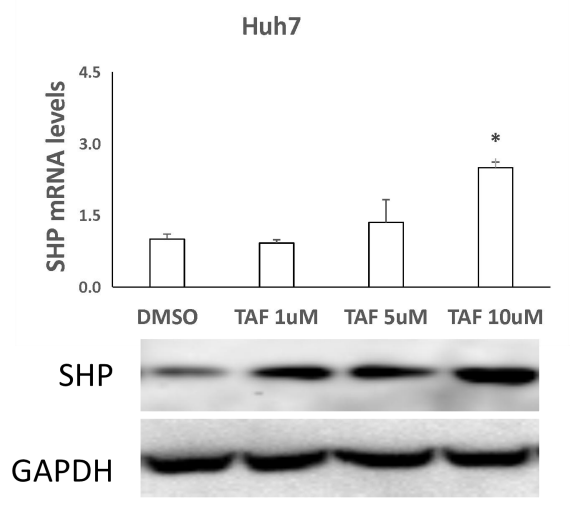

$\mathrm{B}$
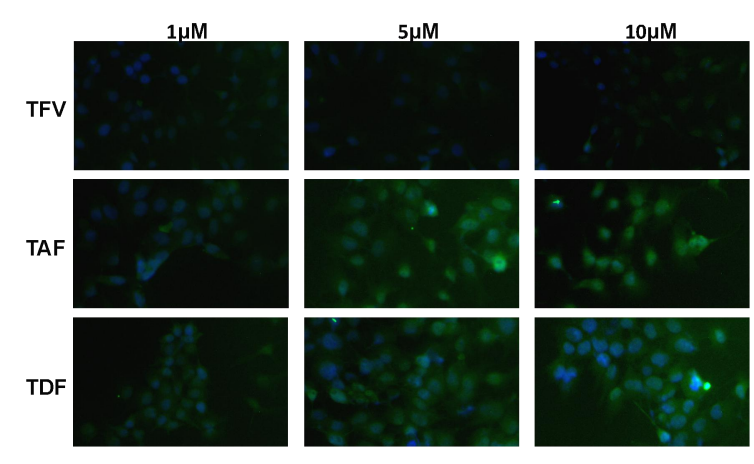

$\mathrm{D}$

Figure 2. SHP regulation by treatment of TFV, TAF and TDF in Huh7 cells. Huh7 cells were seeded in 24-well plates, and then treated with different concentrations of TFV, TAF and TDF for two days. One part of cells were then lysated by RNA Bee for mRNA collection. Complimentary DNA were prepared from the collected mRNA by RT-PCR, and then SHP mRNA expression was measured through Taqman probes by qPCR with GAPDH as the control. The other part of cells were washed by PBS and sonicated in $100 \mathrm{mM}$ Tris- $\mathrm{HCl}$ to collect protein. Protein samples were then subjected to $7.5 \%$ SDS-PAGE and Western Blot for SHP protein level analysis with GAPDH as the internal control. Huh7 cells were also seeded on 8 -well chamber slides at $2 \times 10^{4}$ cell/well, and then treated with the same strategy. Cells were then fixed, washed by PBS, permeablized by $0.1 \%$ Triton-X and blocked by $1 \%$ BSA in PBS for $3 \mathrm{hr}$, and then incubated with SHP primary antibody over night. Slides were stained by DAPI and Alexa Fluor ${ }^{\circledR} 488$ conjugated Goat anti-Rabbit IgG, and images were taken by EVOS microscope. (A) TFV activity on SHP expression in mRNA and protein levels; (B) TAF activity on SHP expression in mRNA and protein levels; (C) TDF activity on SHP expression in mRNA and protein levels; (D) ICC images of the changes of SHP (green) and nucleus (blue) with different concentrations of anti-viral reagents. The statistics was calculated by R-Studio through Post hoc - ANOVA (*represents $\mathrm{p}<0.05$, and $* *$ represents $\mathrm{p}<0.01)$. 


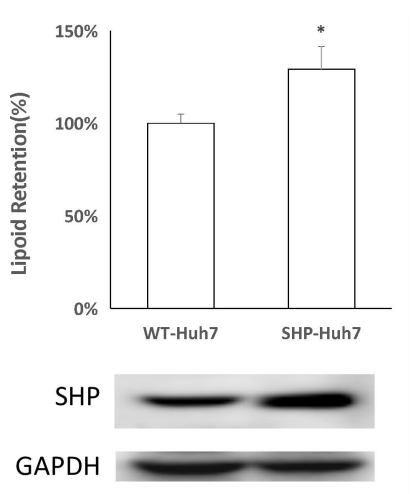

A
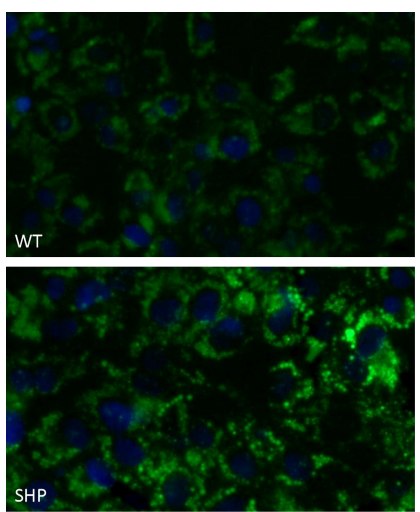

B

Figure 3. Lipid retention in Huh7 cells with SHP transfection. SHP plasmids were transiently transfected to Huh7 cells, and cells were then reseeded into black 96-well plates with clear bottom. (A) Cells were treated with $400 \mu \mathrm{M}$ Oleic Acid for one day, and lipid retention was presented by the florescence intensity. (B) Images were taken to further confirm the results in wild type Huh7 and SHP-Huh7. The statistics were calculated by R-Studio through Post hoc - ANOVA (*represents $\mathrm{p}<0.05$ ). 


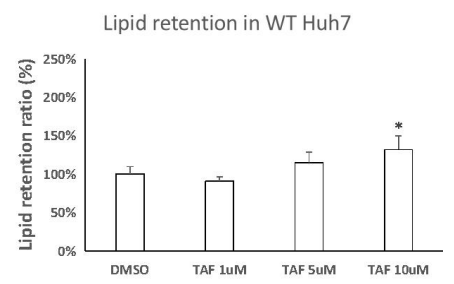

A

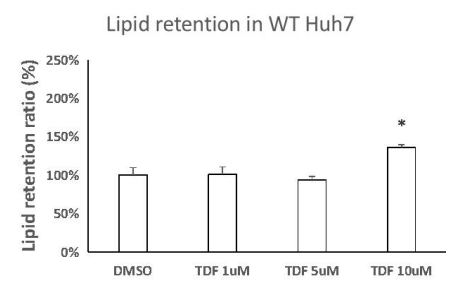

D

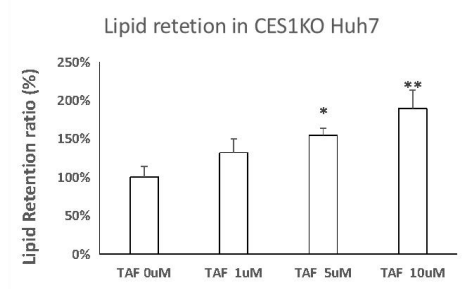

B

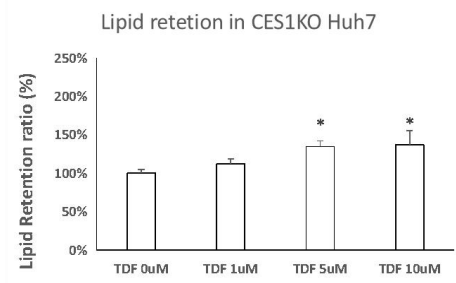

$\mathrm{E}$

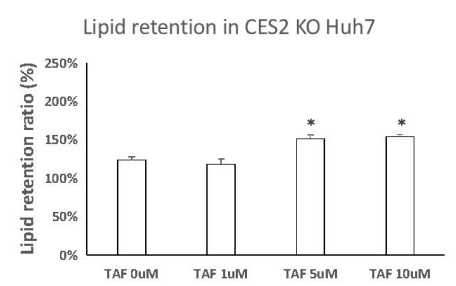

$\mathrm{C}$

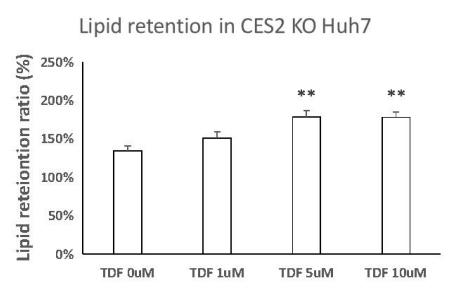

$\mathrm{F}$

Figure 4. Lipid retention profiles in CRISPR screened Huh7 cells. CES1 KO and CES2 KO Huh7 cells were prepared by the transfection of targeting gene CRISPR/Cas9 plasmids and the selection by flow cytometry. (A) Wild type Huh7 cells were treated with different concentrations of TAF, and lipid retention was presented by the fluorescent intensity of nile red staining. (B) CES1 KO Huh7 were treated with different concentrations of TAF, and lipid retention was presented by the fluorescent intensity of nile red staining. (C) CES2 KO Huh7 were treated with different concentrations of TAF, and lipid retention was presented by the fluorescent intensity of nile red staining. (D) Wild type Huh7 cells were treated with different concentrations of TDF, and lipid retention was presented by the fluorescent intensity of nile red staining. (E) CES1 KO Huh7 were treated with different concentrations of TDF, and lipid retention was presented by the fluorescent intensity of nile red staining. (F) CES2 KO Huh7 were treated with different concentrations of TDF, and lipid retention was presented by the fluorescent intensity of nile red staining. The statistics was calculated by R-Studio through Post hoc - ANOVA (*represents $\mathrm{p}<0.05$, and $* *$ represents $\mathrm{p}<0.01)$. 


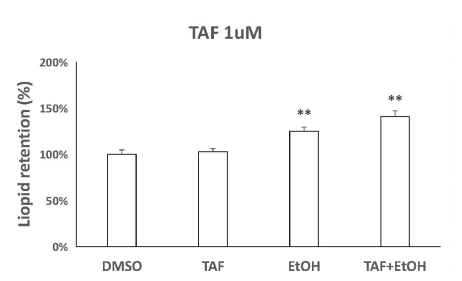

A
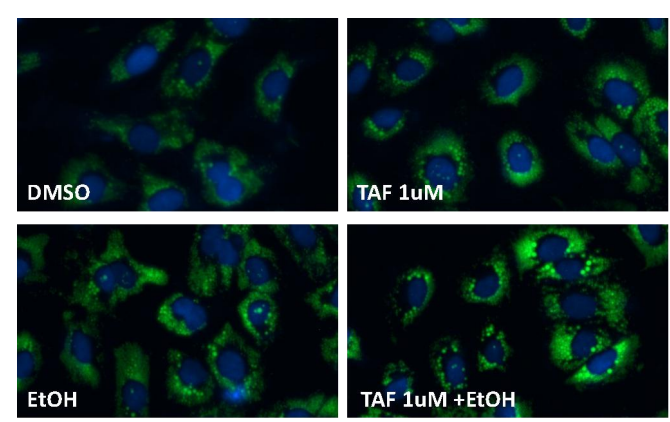

TAF 5UM

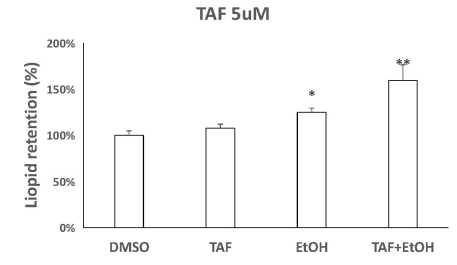

B

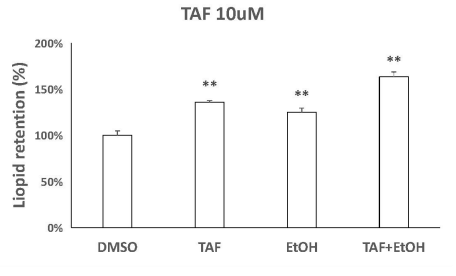

$\mathrm{C}$
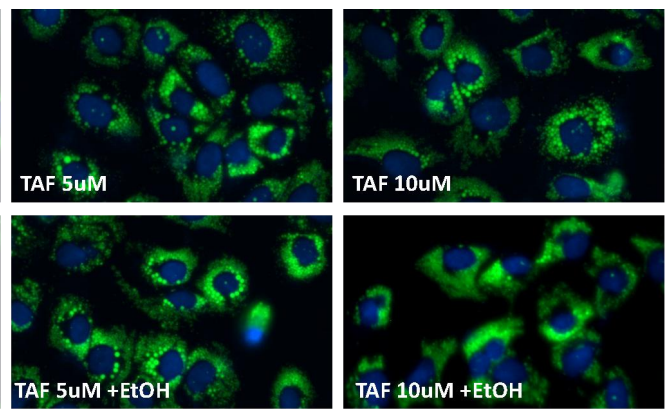

$\mathrm{D}$

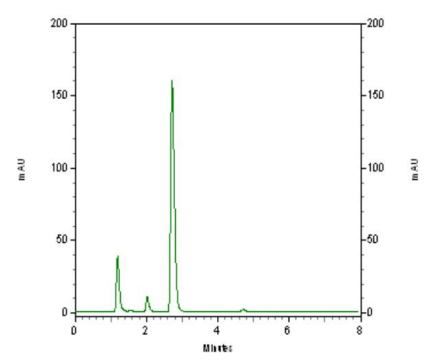

$\mathrm{E}$

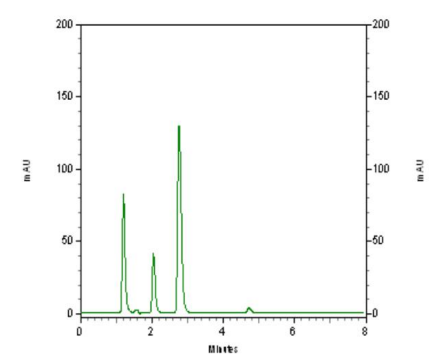

$\mathrm{F}$

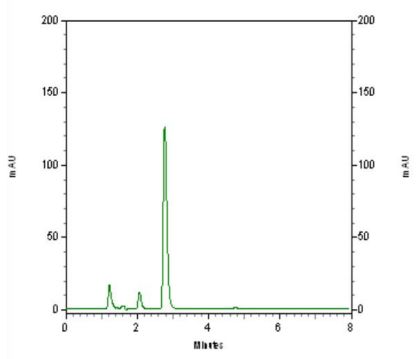

G

Figure 5. Lipid retention profile of TAF treatment in Huh7 cells co-treated with alcohol. (A) Huh7 cells were co-treated with $1 \mu \mathrm{M}$ TAF and $200 \mathrm{mM}$ EtOH, and the lipid retention was presented by the fluorescent intensity of Nile red. (B) Huh7 cells were co-treated with $5 \mu \mathrm{M}$ TAF and $200 \mathrm{mM}$ EtOH, and the lipid retention was presented by the fluorescent intensity of Nile red. (C) Huh7 cells were co-treated with $10 \mu \mathrm{M}$ TAF and $200 \mathrm{mM} \mathrm{EtOH}$, and the lipid retention was presented by the fluorescent intensity of Nile red. (D) Images of the treatments with TAF alone in different concentrations, EtOH alone, and the co-treatments. Mouse (E), Rat (F) and Human $(\mathrm{G})$ liver microsomes $(0.2 \mu \mathrm{g} / \mu \mathrm{L})$ were incubated with $400 \mathrm{mM}$ EtOH and 400 $\mu \mathrm{M}$ TAF in $37^{\circ} \mathrm{C}$ for $90 \mathrm{~min}$, and the mixtures were subjected to HPLC analysis. The statistics was calculated by R-Studio through Post hoc - ANOVA (*represents $\mathrm{p}<0.05$, and $* *$ represents $\mathrm{p}<0.01)$. 